\title{
ESG Practices and the Cost of Debt: Evidence from EU Countries
}

\author{
Yasser Eliwa a ${ }^{\text {ahmed Aboud }}{ }^{\mathrm{b}}$ \& Ahmed Saleh ${ }^{\mathrm{c}}$ \\ ${ }^{a}$ Loughborough University \\ ${ }^{b}$ University of Portsmouth \\ c University of Coventry
}

\begin{abstract}
Using legitimacy and institutional theories, this study investigates whether lending institutions reward firms in $15 \mathrm{EU}$ countries for their environmental, social and governance (ESG) performance and disclosure in terms of lowering their cost of debt capital. Our study distinguishes between ESG performance that is used to indicate an effective commitment to ESG strategies, and ESG disclosure that represents an effort to construct an image of commitment designed to positively influence stakeholders' perceptions. Supporting a version of legitimacy theory, we find that lending institutions value both ESG performance and disclosure and integrate ESG information in their credit decisions - in that firms with stronger ESG performance have a lower cost of debt, and ESG disclosure has an equal impact on the cost of debt as ESG performance. Although these findings suggest that the market (in context) can engender more desirable social outcomes by rewarding ESG practices, it fails to distinguish between ESG performance and disclosure (which may be contrasted as the more substantive and the more symbolic). Moreover, our results also reflect upon the importance of the role that civil society and the state play in addressing and exploring the limitations of free-market regimes. Specifically, we provide evidence that the impact of ESG performance and disclosure on the cost of debt is more dominant in the stakeholder-oriented countries (where the community is more prevalent). Our main findings are robust to a battery of sensitivity tests, including an alternative measure of the cost of debt, model specifications, and different approaches to address endogeneity. We acknowledge limitations in our research method but point nevertheless to its value in supporting a critical perspective and make suggestions for future research.
\end{abstract}

Keywords: ESG performance; ESG disclosure; the cost of debt; credit ratings; EU. 


\section{Introduction}

Different groups of corporate stakeholders have been exercising pressure on firms to go beyond the legally required level of environmental, social and governance $\left(\mathrm{ESG}^{1}\right)$ practices and improve their impact on the environment and society. This rising trend was found by the latest Nielsen Global Survey on Corporate Social Responsibility in 2015 which reveals that $66 \%$ of global consumers are willing to pay more for sustainable brands compared to 55\% in 2014, and that $73 \%$ of global millennials are willing to pay extra for sustainable offerings compared to $50 \%$ in $2014 .^{2}$ In this regard, most market-based research nowadays argues that efficient implementation of ESG practices enhances corporate financial performance (Hillman and Keim, 2001; Birindelli et al., 2015; Hoepner et al., 2016), as it creates and maintains a corporate competitive advantage (Hart, 1995; Shrivastava, 1995; Russo and Fouts, 1997; Aragón-Correa, 1998) by establishing long-term relationships with key corporate stakeholders (Freeman, 1984; Jones, 1995; Donaldson and Preston, 1995). According to a recent study by the United Nations, $89 \%$ of CEOs from more than 100 countries believe that their commitment to ESG practices is translating into real impact in terms of the financial success of their firms (United Nations, 2016).

Despite this wide recognition of the importance of ESG practices and the many positive initiatives globally that have been in place in relation to social and environmental practices, the world is still suffering from social inequities, violence, lack of basic requirements of life, and the state of the environment in general seems to be getting worse (Deegan, 2017). We believe this deterioration in the state of the environment and societies, in general, is the responsibility of business firms and governments and their failure to fulfil their obligations. As Deegan and Shelly (2014) point out, governments tend to believe that social and environmental practices should remain voluntary and be determined by market forces (in context) and take the side of business firms when it comes to debates about extending corporate accountability. A striking example of governments taking the side of firms at the expense of the wider community is how the United States President Donald Trump views the climate change treaty. He stated that this treaty would undermine the US economy and puts US firms at a permanent disadvantage. In

\footnotetext{
${ }^{1}$ The terms CSR and ESG are used interchangeably in this paper.

${ }^{2}$ For more details on the Nielsen Global Survey visit: https://www.nielsen.com/eu/en/press-room/2015/consumer-goodsbrands-that-demonstrate-commitment-to-sustainability-outperform.html.
} 
2017, Donald Trump announced that the US participation in the 2015 Paris Agreement on climate change mitigation is suspended. Despite the increasingly deteriorating state of the environment and societies, business firms predominantly oppose any attempts to make social and environmental practices compulsory (Owen et al., 2000; Deegan and Shelly, 2014). Similarly, social and environmental practices have been criticised in the social accounting literature for their lack of relevance and for their failure to affect sustainable development (Gray, 2010; Husillos et al., 2011).

This debate across the social accounting and market-based literature could be linked to the organisational legitimacy theory of Ashforth and Gibbs (1990). They identify two approaches firms follow regarding social and environmental disclosure: (1) The substantive approach, according to which social and environmental disclosure reflects actual changes in firms' activities; (2) the symbolic approach, which involves the portrayal of firms' behaviour to show the firms to be consistent with social norms while their actual performance and policies may not change (Ashforth and Gibbs, 1990). Firms follow the second approach mainly to convince their key stakeholders, including lending institutions, to believe that they are committed to societal expectations irrespective of the extent to which it actually is or not (Michelon et al., 2015). Empirically, there has been a lack of research on which approach (substantive versus symbolic) firms follow to disclose their social and environmental performance. Most social accounting literature links social and environmental disclosure to the symbolic approach (Patten, 2002; Cho and Patten, 2007), while most of the market-based research links social and environmental disclosure to the substantive approach (Cormier and Magnan, 2007; Clarkson et al., 2008; Dhaliwal et al., 2012; Moser and Martin, 2012; Ge and Liu, 2015; Stellner et al., 2015; Erragragui, 2017).

These two contrasting views have motivated a sizeable amount of research on the economic consequences of ESG practices. There is, however, a scarcity of studies that examine the impact of ESG practices on the cost of debt (Erragragui, 2017). Consequently, little is known on whether lending institutions care about both ESG performance and disclosure of borrowing firms, and whether the effect of ESG disclosure in the absence of ESG performance (the symbolic approach) has a significant impact on lending institutions. Prior studies examining the association between ESG practices and the cost of debt either focused on a single country (e.g., Ge and Liu, 2015; Erragragui, 2017; Hasan et al., 2017) or used a small sample size (e.g., 
Hoepner et al., 2016; Jung et al., 2018; Stellner et al., 2015). Also, they used either ESG performance or ESG disclosure exchangeably as a measure of ESG practices. However, we believe that these two measures of ESG practices are different. While ESG performance measures what firms actually do, ESG disclosure is the communication of their ESG performance (Deegan, 2017), which respectively could be seen as the substantive approach and the symbolic approach.

Drawing on the legitimacy theory, our study empirically examines the impact of firms' ESG performance and disclosure on their cost of debt, and whether ESG disclosure has a moderating effect on the relationship between ESG performance and the cost of debt using a large sample obtained from 15 countries in the EU. We believe that ESG practices represent a crucial factor in determining the creditworthiness of a firm by lending institutions. We argue that lending institutions incorporate firms' ESG information in their lending decision to evaluate two types of risks imposed by these firms: default risk ${ }^{3}$ and reputational risk ${ }^{4}$ (Weber et al., 2010; Weber et al., 2014). Therefore, integrating information on a firm's ESG practices may mitigate these risks, reducing the cost of debt charged to that firm by lending institutions.

Moreover, firms' practices are regulated by a whole series of forces that are never separate from each other, but these forces, such as the state, the market and community, can vary in their influence between contexts (Streeck and Schmitter, 1985). According to institutional theory, organisations adapting their processes to be aligned with externally codified rules, norms, or laws and with best practices in the sector (DiMaggio and Powell, 1983). Thus, ESG practices are shaped by deep-seated institutions rather than only by organisational-level microfactors. In such a setting, we argue that country' sustainability settings will determine the level of ESG performance and disclosure, as well as the market reward of these practices. To help better understand and define the impact of institutional forces on the relationship between the cost of debt and both ESG performance and disclosure, we investigate whether country sustainability characteristics, which can represent those forces, have a moderating effect on the relationship between firms' ESG practices and their cost of debt. Prior studies fail to control

\footnotetext{
${ }^{3}$ Default risk is the risk of losing the principal amount of the loan, in addition to any remediation costs that the lending institution has to carry Thompson, P. \& Cowton, C. J. (2004) Bringing the environment into bank lending: implications for environmental reporting. The British Accounting Review, 36(2), 197-218..

${ }^{4}$ Reputational risk is the risk of linking the lending institution as a financial facilitator to a firm's negative ESG practices ibid..
} 
for country sustainability characteristics while examining this relationship. Therefore, it is not clear in prior studies whether country sustainability characteristics affect the relationship between the cost of debt and both ESG performance and disclosure.

This study contributes to the existing literature in different ways. First, it adds to the limited number of prior studies that examine the impact of firms' ESG performance and disclosure on their cost of debt, which provide conflicting results (Ye and Zhang, 2011; Aman and Nguyen, 2013; Hoepner et al., 2016; Crifo et al., 2017; Erragragui, 2017; Hasan et al., 2017). Using a sample of 6,018 firm-year observations of listed firms in the EU from 2005 to 2016, we find a significant negative association between the cost of debt and both ESG performance and disclosure. This finding sheds light on the significant role of ESG practices nowadays in lending institutions' creditworthiness valuation models. If lending institutions were to demand more ESG information, their relatively powerful position could motivate firms to strengthen their ESG performance and disclosure, which will be of benefit to other stakeholder groups.

Second, this study benefits from a unique data set obtained from the DataStream (ESGASSET4) and Bloomberg databases, which allows measuring both ESG performance and disclosure for the same firm sample list. In contrast to prior studies that examine the impact of ESG performance solely on the cost of debt, this study examines the impact of both ESG performance and disclosure. We believe that the two measures of ESG practices are different. While ESG performance refers to the actual ESG-related activities conducted by the firm, ESG disclosure is the channel through which it announces these activities to its stakeholders. Disclosure can support the substantive approach or the symbolic approach. Therefore, we extend the contribution of this study by investigating the moderating effect of ESG disclosure on the relationship between ESG performance and the cost of debt. In this regard, we report evidence that ESG disclosure acts as a substitute, rather than as a compliment, to ESG performance in decreasing firms' cost of debt. This indicates that firms with poor ESG performance try to increase ESG disclosure to compensate (the symbolic approach). We provide evidence that ESG disclosure is more likely to be undertaken as a symbolic approach in the EU market, which is consistent with the social accounting literature in concluding that CSR disclosure is a tool to manage corporate image, instead of a substantive improvement in the accountability process (Moneva et al., 2006; Merkl-Davies and Brennan, 2007; Hopwood, 2009; Cho et al., 2012b; Michelon et al., 2015). 
Third, in addition to using a comprehensive measure of ESG performance and disclosure, this study offers isolation of the impact of the individual dimensions of ESG performance and disclosure on the cost of debt. Mattingly (2017) point out the importance of using individual dimensions of ESG practices, in addition to a comprehensive measure, to capture the impact on the cost of debt. We provide evidence that lending institutions do value individual dimensions of ESG performance and disclosure, with the environmental dimension having the largest impact on the cost of debt.

Finally, this study contributes to the existing literature by investigating the moderating effect of country sustainability characteristics on the relationship between ESG practices and the cost of debt. While most of the prior research has focused mainly on country sustainability characteristics as a driver of ESG performance or disclosure (e.g., Jackson and Apostolakou, 2010; Ioannou and Serafeim, 2012), our study addresses its role in affecting the anticipated benefits of ESG performance and disclosure. We provide evidence that the impact of ESG performance and disclosure on the cost of debt is more obvious in countries that are more stakeholder-oriented. By doing so, we add to our understanding of how country sustainability characteristics explain the variations in the benefits associated with ESG practices. Also, this finding is consistent with the institutional theory that documents the significant role of institutional factors.

The remainder of this paper is structured as follows: Section 2 discusses the theoretical perspectives on ESG practices, then reviews prior studies and develops hypotheses. Section 3 explains the methodology of the study. Section 4 discusses the main tests and results, in addition to robustness tests conducted. Finally, Section 5 concludes.

\section{Theoretical framework on ESG practices}

The academic debate on whether CSR practices have positive or negative economic consequences on firms started more than 50 years ago. During this period of time, different theories have been used to explain CSR practices such as agency, stakeholder, legitimacy and institutional theories. On one side, in 1958, Levitt expressed his concerns about firms' CSR practices and pointed out that "welfare and society are not the corporation's business. Its business is making money, not sweet music" (Levitt, 1958, p.47). This perspective is consistent with the credit decisions made by lending institutions based on the financial position and 
performance of the borrowing firm to estimate its default risk (Devalle et al., 2017). According to Levitt (1958), lending institutions are interested in verifiable and objective information, such as profitability, leverage, and liquidity of the borrowing firm to ensure its ability to repay the debt. Levitt's perspective was supported by Hemingway and Maclagan (2004), who point out that motivation for engaging in CSR practices is "greenwashing" to cover up for corporate misbehaviour. This, in turn, results in a riskier profile and a higher cost of debt for these firms (Jensen and Smith, 1985). On the other side, theories and recent empirical studies supporting the notion that ESG practices and firm profitability are not inversely related have started to emerge (Scholtens, 2006; Scholtens, 2009; Zeidan et al., 2015), indicating that firms' profitability is no longer enough for lending institutions to make their credit decisions (Birindelli et al., 2015; Hoepner et al., 2016).

Based on legitimacy theory, firms continually aim to ensure that they are perceived as operating within the bounds and norms of their societies (Deegan and Unerman, 2011). So, firms attempt to ensure that their activities are perceived by externals as being legitimate. Therefore, firms should adopt practices that are able to influence societal appraisal to increase their legitimacy such as social and environmental practices including real activities and/or disclosure (DiMaggio and Powell, 1983; Deephouse, 1996; Suchman, 1995). In this regard, Neu et al. (1998), who use an impression management lens that can be linked to legitimacy theory, suggest that financial stakeholders such as banks are the most important stakeholder to the firms and that disclosures will be primarily tailored towards them in order to more effectively meet their needs.

It is argued in the literature that society progressively assumes that firms will "... make outlays to repair or prevent damage to the physical environment, to ensure the health and safety of consumers, employees, and those who reside in the communities where products are manufactured and wastes are dumped ..." (Tinker and Neimark, 1987, p. 84). Therefore, firms with a poor ESG performance might find it difficult to get the necessary support and resources to continue working in a community that values ESG practices, e.g., higher cost of debt. Legitimacy theory emphasises that firms should consider the rights of the public at large, not merely those of its investors. Failure to comply with societal expectations might lead to sanctions being imposed by society in the form of legal restrictions imposed on a firm's 
operations, or provide the firm with limited resources (e.g., higher cost of debt capital) (Deegan and Unerman, 2011).

While ESG disclosure is growing significantly in recent years, a clear debate has grown in the literature about the motivation behind adopting a specific ESG disclosure approach (e.g., Neu et al., 1998; Lewis and Unerman, 1999; Kolk et al., 2008; Ball and Craig, 2010; Burritt and Schaltegger, 2010; Cho et al., 2012a; Cho et al., 2015). This debate can be referenced to two main approaches. Firstly, the substantive management approach, which explains that the motivation for adopting ESG disclosure strategy is to gain legitimacy through real changes in the firms' actions through aligning their strategies to social norms. However, the second approach, named symbolic management approach, in which firms are engaging in apparent actions to affect stakeholders' perceptions (Ashforth and Gibbs, 1990). Engaging in those apparent actions lead stakeholders to believe that firms are committed to societal requirements (Ashforth and Gibbs, 1990). Based on this approach, firms with weak ESG performance tend to increase their level of ESG disclosure above their actual ESG performance (greenwashing) to gain the benefits associated with ESG practices, e.g., lower cost of debt. In this regard, recent research argues that firms use hypocrisy strategies to manage different stakeholder interests to maintain legitimacy (Brunsson, 2007; Cho et al., 2015). In other words, firms maintain legitimacy through "camouflaging" their practices (Michelon et al., 2016). This framework offers a rich theoretical lens to explore how lending institutions as a main stakeholder group perceive ESG performance and disclosure. Therefore, whether ESG practices are used under a substantive or symbolic approach is, therefore, remains an open question.

Within the substantive approach, it is expected to find that ESG disclosure acts as a compliment to ESG performance as it is driven by honest interest to improve transparency, the quality of information communicated and improve stakeholders' engagement process. However, within the symbolic approach, it is expected to find evidence that ESG disclosure acts as a substitute, rather a compliment, to ESG performance as disclosure might be used to show firms as “committed" (Guidry et al., 2012), and disclosure used here to facilitate the construction of an inaccurate company image (Hopwood, 2009).

Although stakeholder and legitimacy theories have been adopted as popular explanations of social and environmental practices, they remain silent on politico-economic context (Gray et 
al., 1995; Spence et al., 2010; Deegan, 2010). Gray et al. (1995) delineate stakeholder and legitimacy theories as concerned with the legitimacy of firms whereas the institutional theory is defined as concerned with the legitimacy of the system. In this regard, ESG practices are viewed as "a social phenomenon that emerges from the actions and interactions of agents within a complex set of forces, including external economic forces and related ideologies, national economic conditions, state policies" (Ahmed and Uddin, 2018, p. 2211). Given its societal orientation, ESG practices may be explained as an embedded practice shaped by deepseated institutions rather than only by organisational-level micro-factors.

Prior studies have provided evidence that diverse institutional contexts lead to a variation in firm-level ESG performance and disclosure (e.g., Ahmed and Uddin, 2018; Baldini et al., 2018). DiMaggio and Powell (1983) theorised that organisations adapting their processes to nourish their legitimacy through the adoption of coercive (i.e. alignment with externally codified rules, laws, or norms), mimetic (i.e. alignment with best practices or managerial fads/fashions) or normative isomorphism (i.e. alignment with espoused standards set by educational/professional authorities). For instance, Matten and Moon (2008) document that pertinent social obligations are seen in Europe as the purview of government whereas US-style ESG practices are characterised by less regulation and more incentive and opportunity for business organisations to fill social niches.

In such a setting, decisions regarding ESG issues are framed vis a vis a broader social context and thereby the level of ESG performance and disclosure, as well as the market reward of these practices, vary across countries because of the diversity in the institutional settings (Jackson and Apostolakou, 2010; Baldini et al., 2018). In particular, we argue that the market will reward ESG practices when stakeholder orientation 'community' is more prevalent. By doing so, our study contributes to not only the existing academic debate around ESG practices but also related policies and regulations. 


\section{Hypothesis development}

\subsection{The impact of ESG performance and disclosure on the cost of debt}

The growing attention paid to ESG issues ${ }^{5}$ has led to an increase in lending institutions' awareness of reputational risk imposed by borrowing firms in addition to default risk. This means that lending institutions can be perceived by society as facilitators of negative ESG practices conducted by borrowing firms, resulting in adverse stakeholder reactions to these lending institutions. These risks represent incentives for lending institutions to integrate ESG information into their creditworthiness evaluation process.

The recognition of this link by lending institutions and other stakeholder groups increased since many lending institutions around the world signed the United Nations Environment Programme's Statement by Banks on the Environment and Sustainable Development (UNEP, 2012). Thereafter, lending institutions started to integrate ESG information in their internal operations by including it in their checklist for risk assessment and management. Thompson and Cowton (2004) find that $60 \%$ of banks in the UK had a formal corporate lending policy which incorporated ESG considerations. Furthermore, the increasing awareness of ESG practices by society also provides lending institutions with an opportunity to make their ESG stance central to their activities or brands (Thompson and Cowton, 2004; Weber et al., 2014). For example, the Co-operative Bank in the UK declined to grant loan facilities to business clients due to ESG concerns (Kitson, 1996). Zeidan et al. (2015) also point out that incorporating ESG information in a bank's credit-granting policy creates a long-term presence on the market by emphasising its own contribution to the environmental quality and society.

Despite the worldwide recognition of the importance of ESG practices by firms, their impact on the cost of debt in academia is still a controversial issue. On the one hand, some studies provide evidence of the inverse relationship between ESG performance and the cost of debt (Hasan et al., 2017; Ge and Liu, 2015; Goss and Roberts, 2011; Ye and Zhang, 2011; Crifo et al., 2017) On the other hand, other studies find an insignificant or even a positive relationship between ESG performance and the cost of debt (Erragragui, 2017; Stellner et al., 2015; Hoepner et al., 2016). The conceptual link between ESG disclosure and the cost of debt is even

\footnotetext{
${ }^{5}$ United Nations (UN) Sustainable Stock Exchange (SSE) initiative requires all large firms to report their ESG practices by 2030 at the latest (SSE, 2015).
} 
more obvious. ESG disclosure is different from ESG performance because it provides additional information, such as, a risk management framework that demonstrates the firms' awareness of their ESG weaknesses and how it is going to mitigate their negative impacts. For example, Jung et al. (2016) find that lending institutions incorporate a firm's exposure to carbon-related risk into lending decisions, and that the impact of that risk on increasing its cost of debt is mitigated when the firm shows awareness of the risk and willingness to decrease through disclosure of plans for new capital investments using green technology. Furthermore, a higher level of ESG disclosure is linked to lower information asymmetry between borrowing firms and lending institutions, and hence lowers the cost of debt. In a similar vein, Dennis and Mullineaux (2000) point out that as information about the borrowing firm becomes more transparent, the debt contract becomes more saleable. Aman and Nguyen (2013) find that firms can mitigate agency conflicts and reduce risk to debtholders by lowering information asymmetry through a higher level of disclosure.

Although this conceptual link between ESG disclosure and the cost of debt is clear, there is a scarcity of empirical studies that examine this association. Of particular importance to our study, Dhaliwal et al. (2011a) examine internal control disclosure by 577 US-listed firms as a mechanism of corporate governance and its impact on the cost of debt. They provide evidence that disclosure of corporate governance material weaknesses results in increased cost of debt. Gao et al. (2016) examine disclosure level of corporate social responsibility by 61 firms listed on the Amsterdam Stock Exchange between 2004 and 2012 and found an inverse relationship between corporate social responsibility disclosure and the cost of debt. Based on the above discussion, we posit the following two hypotheses:

$\mathrm{H}_{1 \mathrm{a}}$ : There is a negative relationship between firms' ESG performance and their cost of debt.

$\mathrm{H}_{1 \mathrm{~b}}$ : There is a negative relationship between firms' ESG disclosure and their cost of debt.

\subsection{The moderating effect of ESG disclosure on the relationship between ESG performance and the cost of debt.}

While accounting standards require specific ESG information to be disclosed in the annual reports (e.g., asset retirement obligations, contingencies related to environmental clean-up, 
etc.), the significant portion of ESG disclosure remains voluntary and unregulated (Fatemi et al., 2017; Nazari et al., 2017). This has resulted in variations in the level of ESG disclosure by firms. A large percentage of these variations is determined by ESG performance as a major determinant of the ESG disclosure policy adopted by firms. Many studies find a significant association between the two components of ESG practices (Al-Tuwaijri et al., 2004; Clarkson et al., 2008). As mentioned in the theoretical framework section, Ashforth and Gibbs (1990) determine two approaches that firms follow regarding social and environmental disclosure. Firms use the substantive approach to pose themselves in the market as being committed to a strong ESG performance and distinguish themselves from poor ESG performers (Cahan et al., 2016). However, the lack of regulation of ESG disclosure provides managers with an opportunity to deliberately manipulate their ESG disclosure to signal high ESG commitment when their ESG performance is actually poor (the symbolic approach). For example, Nazari et al. (2017) find that firms listed on the S\&P 500 index with poor ESG performance intensify their ESG disclosure by using more complex syntax that is difficult to understand, aiming to impress readers in order to hide poor performance. Also, Michelon et al. (2015) find that UK listed firms tend to dilute information in their CSR stand-alone report with other pieces of irrelevant information, portraying the firm as CSR committed and camouflaging important items of its disclosure. Other studies, in contrast, argue that managers might fear that investors would punish them for the high costs of ESG practices. Therefore, managers choose to understate their actual ESG performance (brownwashing) (see Kim and Lyon, 2014).

Prior studies provide mixed results on the relationship between ESG performance and ESG disclosure, with the majority indicating a positive relationship (Al-Tuwaijri et al., 2004; Clarkson et al., 2008; Dhaliwal et al., 2011b; Lyon and Maxwell, 2011; Gao et al., 2016), while others find a negative relationship (Hughes et al., 2001; Patten, 2002). Therefore, this study extends the existing literature by providing insights into the effects of the interplay between ESG performance and disclosure on the cost of debt, thereby shedding light on managers' choices with respect to ESG performance and disclosure. Given the contradictory results driven by different managerial motives for ESG disclosure (the substantive approach vs the symbolic approach), we posit the following non-directional hypothesis:

$\mathrm{H}_{2}$ : The interaction between firms' ESG performance and disclosure has a significant impact on their cost of debt. 


\subsection{The moderating effect of country sustainability characteristics on the relationship between ESG practices and the cost of debt.}

It has been established that country sustainability characteristics play a vital role in driving firms' behaviour, based on the notion that firms are embedded in a broad set of political and economic institutions (Campbell, 2007; Aguilera et al., 2007). Prior literature documents that country sustainability characteristics affect financial reporting practices and the related outcomes (Ball et al., 2000; Ball, 2006; Leuz, 2010; Byard et al., 2011; Ahmed et al., 2013; Manganaris et al., 2015; Christensen et al., 2016). Regarding ESG performance and disclosure, Baldini et al. (2016) report evidence that country-level characteristics, such as legal framework, and cultural system significantly affect firms' ESG disclosure. Likewise, drawing from institutional theory, Ioannou and Serafeim (2012) reveal that the country's financial and political system, as well as the education and labour system, have effects on firms' social and environmental performance. Furthermore, Jackson and Apostolakou (2010) document that firms from Anglo-Saxon countries provide higher CSR disclosures than firms in Continental Europe.

In fact, there is still ongoing debate regarding the effects of the interaction between institutional factors and corporate reporting practices on the anticipated economic consequences (Li, 2010; Daske et al., 2008; Ahmed et al., 2013; Moscariello et al., 2014; Manganaris et al., 2015; Christensen et al., 2016). Daske et al. (2008) find that the capital-market benefits (market liquidity and the cost of capital) following IFRS adoption occurred only in countries where legal enforcement is strong. Likewise, Manganaris et al. (2015) reveal that banks from countries characterised by strong enforcement show greater value relevance after the adoption of IFRS compared to other banks from countries characterised by weak enforcement.

In contrast, Houqe et al. (2014) find a stronger relationship between IFRS and accounting quality in countries with low levels of investor protection. Also, Ahmed et al. (2013) find that the enforcement regime does not affect accounting quality and related consequences if the regulations are looser and permit more managerial discretion. Likewise, Moscariello et al. (2014) find that the mandatory adoption of IFRS has a significant positive relationship with the debt-contracting process in Italy, which is characterised by a weak investor protection system, but that it has had no effect in the UK, which is characterised by strong enforcement. However, 
Florou and Kosi (2015) find that the reported debt market benefits are present even for EU countries that did not experience concurrent financial reporting enforcement or other institutional reforms. In particular, Dhaliwal et al. (2012) find that CSR disclosure is associated with more accurate earnings forecast in countries where stakeholder groups such as employees, consumers, governments, and communities are likely to have greater influences on firms' operational decisions. In a further study, Dhaliwal et al. (2014) indicate that the negative association between the cost equity capital and CSR disclosure is more obvious in stakeholderoriented countries. ${ }^{6}$ Thus, we expect the impact of ESG practices on the cost of debt to be greater in countries that are more sustainable. Therefore, the following hypotheses are generated.

$\mathrm{H}_{3 \mathrm{a}}$ : The anticipated negative impact of ESG performance on the cost of debt is greater in more sustainable countries.

$\mathrm{H}_{3 \mathrm{~b}}$ : The anticipated negative impact of ESG disclosure on the cost of debt is greater in more sustainable countries.

\section{Research design}

\subsection{Variables measurement}

\subsubsection{ESG performance (ESG-perform) and ESG disclosure (ESG-disclose)}

This study investigates the impact of ESG practices on the cost of debt. Two commonly used proxies of ESG practices are available; Thomson Reuters and Bloomberg ESG ratings. While Thomson Reuters ESG ratings, collected from the DataStream (ESG-ASSET4), represent a metric of ESG performance, Bloomberg focuses on a firm's level of ESG disclosure (Ioannou and Serafeim, 2012; Baldini et al., 2016; Fatemi et al., 2017). Thomson Reuters ESG ratings are designed to measure a company's relative ESG performance, commitment, and effectiveness across three main dimensions that cover 10 themes. These dimensions are environmental (resource use, emissions, and innovation), social (workforce, human rights, community, and product responsibility) and governance (management, shareholders, and CSR

\footnotetext{
${ }^{6}$ Stakeholder-orientation is a country level proxy based on several attributes of stakeholders, including legitimacy, power and salience as measured in Dhaliwal et al (2012).
} 
strategy). They are considered a comprehensive evaluation of the company's sustainability impact and conduct based on the reported data in the public domain, and Thomson Reuters ESG controversy score (Thomson Reuters, 2017). ${ }^{7}$ In contrast, ESG disclosure ratings, using the Bloomberg database index, are based on the information available in firms' annual reports, corporate social responsibility reports, and on their websites. Bloomberg ESG disclosure scores rate companies annually based on their disclosure of quantitative and policy-related ESG data (Huber and Comstock, 2017). Bloomberg ESG data includes 120 ESG indicators (e.g., carbon emissions, climate change effect, pollution, renewable energy, political contributions, discrimination, diversity, community relations, and human rights). Moreover, both Thomson Reuters and Bloomberg provide a score for the three individual dimensions [Environmental (E), Social (S), and Governance (G)] to measure ESG performance and the level of its related disclosure.

To test the interaction effects between ESG performance and ESG disclosure, we transform the ESG disclosure score to a dummy variable. We first calculate the median of ESG disclosure every year, then we give the value of one if firms have higher ESG disclosure score than the median, and zero otherwise.

\subsubsection{The cost of debt $(C o D)$}

Our main tests examine whether ESG performance and disclosure affect the cost of debt. To measure the cost of debt, we use the accounting measure, calculated as the ratio of a firm's interest expense to its average debt (Francis et al., 2005; Gray et al., 2009). A meta-analysis conducted by Orlitzky et al. (2003) find that ESG performance is more correlated to accounting-based measures than to market-based measures. Also, credit ratings based on the evaluation of the Fitch agency is used as a robustness measure of the cost of debt. Previous empirical studies have established a relationship between ESG practices and credit ratings as a proxy for the cost of debt. For example, Bauer and Hann (2010) find that legal, reputational, and regulatory risks associated with environmental incidents lead to lower credit ratings. Also, Ashbaugh-Skaife et al. (2006) indicate that credit ratings are affected by corporate governance mechanisms. Other studies used a comprehensive measure of corporate social responsibility

\footnotetext{
${ }^{7}$ For more details on Thomson Reuters ratings methodology visit https://financial.thomsonreuters.com/content/dam/openweb/documents/pdf/financial/esg-scoresmethodology.pdf
} 
and found that better corporate social responsibility performance is associated with better credit ratings (Ge and Liu, 2015; Oikonomou et al., 2014; Devalle et al., 2017).

\subsubsection{Control variables}

Based on prior studies, there are four control variables consistently found to be significantly related to the cost of debt. These variables are the firm size (Size), leverage ( $L E V)$, return on assets (ROA), and interest coverage rate (IntCov). We measure Size as a natural logarithm of total assets in year $t$. We expect to find a negative relationship between Size and the cost of debt. Firms with large Size are expected to have more resources for external finance at a lower cost than those with small Size (Erragragui, 2017; Hasan et al., 2017). LEV is the ratio of total debt to total assets in year $t$. We expect to find a positive association between $L E V$ and the cost of debt. Those firms with a lower level of $L E V$ are expected to have better solvency and lower interest rate than firms with a higher level of $L E V$ (Tran, 2014; Jung et al., 2016; Goh et al., 2016; Erragragui, 2017). ROA is the net income before extraordinary items divided by total assets. A negative association is also expected between $R O A$ and the cost of debt. Firms with high $R O A$ are in better financial position and often acquire loans with lower interest rates (Aman and Nguyen, 2013; Ge and Liu, 2015; Arena, 2018). IntCov is the total operating income divided by total interest expense. IntCov is a measure of a firm's capabilities to pay its interest. So, it is likely that firms with a higher rate of interest coverage to have a lower cost of debt (Francis et al., 2005; Gray et al., 2009; Hoepner et al., 2016; Erragragui, 2017). Moreover, our study uses a combined proxy for country sustainability characteristics (Stake) developed by Dhaliwal et al. (2012) to measure the legal and social norms of different countries. This proxy is based on attributes highlighted by the stakeholder theory describing the relative importance of stakeholder groups such as power, legitimacy, and salience as in Mitchell et al. (1997). This proxy is the principal factor of four attributes related to assessing the legal environment of a country in protecting labour, the existence of country's environmental laws and regulations, the level of public awareness of corporate social responsibility issues, and surveys of the views of corporate executive officers on corporate social activities. ${ }^{8}$ All variables are defined in Appendix A.

${ }^{8}$ For more details: Dhaliwal et al $(2012,2014)$. 


\subsection{Data and sample}

The sample consists of all non-financial firms in $15 \mathrm{EU}$ countries. Due to inadequate observations, the remaining EU countries have been excluded. Although Norway is not a member of the EU, it has been added to the sample because it applies the same accounting standards and regulations as other EU countries. In total, the final sample consists of 6,018 firm-year observations covering the period from 2005 to 2016. In order to avoid any survivorship bias, we include both active and dead equities in our sample. We use Thomson Reuters Asset4 database for both ESG performance and credit ratings. We also use the Bloomberg database for ESG disclosure ratings and Thomson Reuters DataStream for both the cost of debt and control variables. Table 1 reports the number of firms per industry and country. Panel A in Table 1 shows that all industries are well represented in the sample. Approximately $31.2 \%$ of the sample comprises firms from the manufacturing sector, while $21.4 \%$ are from utilities, $15.1 \%$ from retail, $6.1 \%$ from health care services, $5.4 \%$ from information technology, and $7.5 \%$ from mining and oil and gas. Furthermore, panel B in Table 1 shows that all countries of the EU are well represented in the sample with the three major economies in Europe (UK, France and Germany) comprising $63.4 \%$ of the total sample.

\section{[Insert Table 1 here]}

Table 2 reports the descriptive statistics regarding the primary variables; ESG performance, ESG disclosure, the cost of debt, and firm characteristics for the final sample. All continuous variables are winsorised at the $1 \%$ and $99 \%$ percentiles. The average of ESG performance is 0.66 and the median is 0.76 . The average of ESG disclosure is 0.36 , and the the median is 0.36 . The mean (median) of the cost of debt is 0.06 (0.05). The mean of $L E V$ is 0.25 and the median is 0.24 . The mean of Size is 15 and the median is 15 . The values of these variables seem realistic because they fall within the bounds of estimates reported in prior literature (e.g., Francis et al., 2005; Gray et al., 2009; Erragragui, 2017). Also, table 2 reports information on other variables. The average of total assets is $\$ 11,000$ million, and the median of total assets is $\$ 3,000$ million; mean of sales is $\$ 8,300$ million, and median of sales is $\$ 2,500$ million.

\section{[Insert Table 2 here]}

Table 3 reports the correlations among the primary variables. It is noted that the cost of debt is negatively correlated with both ESG performance and its related disclosure. Also, it is 
negatively correlated with Size, ROA and IntCov, and positively correlated with $L E V$, which is consistent with prior studies (Francis et al., 2005; Gray et al., 2009; Goh et al., 2016; Erragragui, 2017; Arena, 2018). Regarding ESG performance, Table 3 shows that it is negatively correlated with $L E V$ and IntCov. Also, the Table shows that ESG performance is positively correlated with ESG disclosure, country stakeholder orientation (Stake), Size, and ROA which are consistent with prior studies (Francis et al., 2005; Gray et al., 2009; Goh et al., 2016; Erragragui, 2017; Arena, 2018).

Moreover, the correlation between ESG performance and disclosure is high (0.61) but far from a perfect correlation suggesting that ESG performance and disclosure capture different attributes of ESG ratings. ${ }^{9}$ This finding is consistent with prior studies that found a correlation between disclosure and performance. For example, Al-Tuwaijri et al. (2004) find that good environmental performance is positively associated with good environmental disclosure. In a recent study, Nazari et al. (2017) examine the relationship between the complexity of corporate social responsibility disclosure and actual corporate social responsibility performance. They find a positive association between actual corporate social responsibility performance and readability and the level of corporate social responsibility disclosure. Indeed, the correlation coefficient also suggests that for at least some companies, the ESG performance and disclosure are negatively correlated or at least not correlated. Therefore, the use of both attributes will provide a clear understanding of the anticipated impact of ESG practices on the cost of debt.

\section{[Insert Table 3 here]}

\section{Main tests and results}

In this section, we present three sets of tests to examine the association between ESG practices and the cost of debt. First, we examine the impact of ESG performance and disclosure along with individual dimensions on the cost of debt. Second, we examine the moderating effect of ESG disclosure on the association between ESG performance and the cost of debt. Finally, we examine the moderating effect of country sustainability characteristics on the association

\footnotetext{
${ }^{9}$ The pivotal point here is the strength of the association between proxies rather than the significance level.
} 
between ESG practices and the cost of debt. Table 4 presents the estimated results for the main models, which is based on Newey and West (1987) standard errors pooled regression. This type of regression is designed to mitigate the problems of autocorrelation and heteroscedasticity effects.

\subsection{ESG practices the cost of debt}

We propose that ESG practices are negatively associated with the cost of debt. We examine the following regression model between ESG performance score, the cost of debt and a set of control variables:

$$
\begin{aligned}
\operatorname{CoD}_{i, t}= & \alpha+\beta_{1} \text { Size }_{i, t}+\beta_{2} \text { LEV }_{i, t}+\beta_{3} \text { ROA }_{i, t}+\beta_{4} \text { IntCov }_{i, t}+ \\
& \beta_{5} \text { ESG }_{i t}^{k}+\beta_{6} \text { Stake }_{i, t}+\beta_{7} \text { YearFixedEffect }_{t}+ \\
& \beta_{8} \text { IndustryFixedEffect }_{i}+v_{i, t}
\end{aligned}
$$

(Equation 1)

where:

$C o D$ is the cost of debt calculated as the ratio of a firm's interest expense to the average debt; Size is the natural logarithm of total assets;

$L E V$ is the total debt of a firm deflated by total assets;

$R O A$ is net income before extraordinary items deflated by total assets;

IntCov is the total operating income deflated by total interest expense;

ESG is the score of ESG practices; K represents either ESG performance or ESG disclosure.

Stake is the average of a country-level score of stakeholders orientation developed by Dhaliwal et al. (2012) with a higher value indicating greater stakeholders orientation.

Following Francis et al. (2005), we include the firm characteristics that are reported to be affecting the cost of debt. Along with ESG-perform and ESG-disclose, we include Size, LEV, ROA, IntCov, and Stake. Table 4 column 1 reports the results of estimating equation 1 using ESG-perform as an independent variable. The results show a significant negative association between ESG performance and the cost of debt. The estimated coefficient of ESG-perform is 0.011 and is statistically significant at $1 \%$ level (t-statistics 2.76). Consistent with our prediction, the result indicates that firms with higher ESG performance have a lower cost of debt. These results can be interpreted as a sign that as ESG performance increases, the amount of interest that lending institutions are willing to receive for a pound of debt for such firms decreases. This means that lending institutions do integrate information about ESG 
performance of borrowing firms when evaluating their risk profile in their lending decision model, which is consistent with previous studies (Goss and Roberts, 2011; Nandy and Lodh, 2012; Aman and Nguyen, 2013; Ge and Liu, 2015; Hasan et al., 2017; Crifo et al., 2017) and thus supports the first hypothesis $\left(\mathrm{H}_{1}\right)$.

\section{[Insert Table 4 here]}

Moving to control variables, we find that the signs of their coefficients are largely consistent with findings in the existing literature (e.g., Francis et al., 2005; Gray et al., 2009; Erragragui, 2017)). In particular, the results show significant negative associations between the cost of debt and Size, ROA and IntCov. Firms with high IntCov have a lower cost of debt, and large firms have a relatively lower cost of debt compared to small firms (Erragragui, 2017; Hasan et al., 2017). Also, the results show that firms with high $L E V$ have a higher cost of debt (Tran, 2014; Goh et al., 2016; Jung et al., 2016; Erragragui, 2017). Finally, the results show that the cost of debt is lower for firms from countries with greater stakeholders orientation such as Denmark than for those firms from countries with lower stakeholders orientation such as Greece (Mitchell et al., 1997; Dhaliwal et al., 2012).

We decompose the total score of ESG performance into their individual dimensions, which are the environmental, the social, and the governance dimensions and test the associations between these dimensions and the cost of debt. Table 5 (panels A) reports the results of estimating equation one after replacing the ESG performance score with its individual dimensions. We find a significant negative association between the cost of debt and both the environmental and social dimensions, but not the corporate governance dimension, of ESG performance. The environmental dimension has the largest impact on the cost of debt with a coefficient of -0.012 ( $t$-statistics -3.41$)$, then the social dimension with a coefficient of -0.012 ( $t$-statistics -3.18 ). The inverse relationship between the environmental and social dimensions of ESG performance and the cost of debt is consistent with prior studies. For example, Hasan et al. (2017) find that higher levels of social capital incur lower bank loan spreads. Jung et al. (2018) find that the environmental impact of high carbon emissions is related to a higher cost of debt. Also, Nandy and Lodh (2012) find that a more eco-friendly firm gets a more favourable loan contract than do the firms with a lower environment score. In addition, Erragragui (2017) examines the impact of environmental and corporate governance dimensions of corporate social responsibility performance. He reports a negative impact for good performance in 
corporate governance on the cost of debt. However, similar to our finding, he reports an insignificant relationship for weaknesses of corporate governance. The insignificant relationship between the corporate governance dimension and the cost of debt is inconsistent with prior studies that provide evidence that good governance is associated with higher credit ratings and lower cost of debt (Aman and Nguyen, 2013; Andrade et al., 2014; Erragragui, 2017).

We argue that the insignificant relationship between the corporate governance dimension and the cost of debt may be offset by the inverse relationship between the environmental and social dimensions and the cost of debt. We believe that lending institutions use the collective and integrative impact of the individual dimensions of ESG performance to determine the reliability and trustworthiness of the firm's management team to make their lending decisions. Many authors emphasised the concept of management quality and its impact on the cost of debt, and how lending institutions take into account risk arising from good or poor management practices concluded from the individual dimensions of ESG performance (e.g., Rahaman and Al Zaman, 2013). This finding suggests the need for further investigation of the effectiveness of corporate governance mechanisms and its impact on the cost of debt.

Regarding ESG disclosure, Table 4 (column 2) reports the results of estimating equation 1 using ESG-disclose as an independent variable. In this regard, the results show a significant negative association between ESG disclosure and the cost of debt. In particular, the estimated coefficient of ESG-disclose is - 0.024 and is statistically significant at 5\% level (t-statistics 2.57), which is consistent with our prediction and previous studies. For example, using a comprehensive measure of corporate social responsibility disclosure, Gao et al. (2016) find an inverse relationship between corporate social responsibility disclosure and the cost of debt. These results provide evidence that actual ESG performance and its related disclosure have an impact on a firm's ability to obtain external finance at a lower cost.

Similar to ESG performance, we decompose the total score of ESG disclosure into its individual dimensions. Consistent with our expectations, results in Table 5 (panel B) reveal that the three individual dimensions have a significant inverse relationship with the cost of debt. The environmental dimension of ESG disclosure has the largest impact on the cost of debt with a coefficient of -0.018 ( $t$-statistics -2.41 ), followed by the corporate governance 
dimension with a coefficient of -0.018 ( $t$-statistics -1.93 ). The social dimension has the lowest impact on the cost of debt with a coefficient of -0.016 ( $t$-statistics -1.68). The largest impact of environmental performance and disclosure on the cost of debt indicates that lending institutions prioritise integrating environmental information in their creditworthiness evaluation process, and most likely for the purpose of evaluating the reputational risk associated with environmental issues imposed by borrowing firms. This finding suggests that firms struggling to finance their ESG practices due to limited resources should devote the largest portion of these resources to their environmental practices.

\section{[Insert Table 5 here]}

In general, these findings are consistent with ESG practice-related theories supporting the notion that firms' ESG practices enhance their financial performance. The negative relationship between ESG practices (performance and disclosure) and the cost of debt indicates that these practices help mitigate the agency conflict between shareholders and debtholders (Jensen and Smith, 1985).

According to stakeholder theory, stewardship theory and transformational leadership theory, ESG practices are used by firms to send a strong signal to lending institutions about the efficiency and integrity of their management. This level of efficiency and integrity is indicated by a management's decision to allocate part of a firm's financial resources to satisfy the needs of different groups of corporate stakeholders (other than shareholders), while at the same time improving the financial performance of firms. This trustworthy behaviour by a firm's management helps lending institutions better value the risk associated with their decisions that can increase the wealth of stockholders while reducing the wealth of debtholders (such as dividend payout, claim dilution, asset substitution and underinvestment), resulting in a lower cost of capital charged to a borrowing firm. Furthermore, ESG practices help reduce information asymmetry between borrowing firms and lending institutions by providing lending institutions with the ESG information necessary to make sure that they are not connected with business activities that have a negative impact on the environment or the broader society, and evaluate the reputational risk associated with their credit decisions. 


\subsection{The moderating effect of ESG disclosure}

To test our second hypothesis that ESG disclosure has a moderating effect on the relationship between ESG performance and the cost of debt, we transform the ESG disclosure score to a dummy variable. We first calculate the median of ESG disclosure every year, then we give the value of one if firms have higher ESG disclosure score than the median and zero otherwise. Then, we include an interaction term between ESG-perform and this variable in our main regression. Our study expects a significant impact of ESG disclosure effect on the relationship between ESG performance and the cost of debt (Al-Tuwaijri et al., 2004; Clarkson et al., 2008; Dhaliwal et al., 2011b; Lyon and Maxwell, 2011; Gao et al., 2016).

$$
\begin{aligned}
\operatorname{CoD}_{i, t}= & \alpha+\beta_{1} \text { Size }_{i, t}+\beta_{2} \text { LEV }_{i, t}+\beta_{3} \text { ROA }_{i, t}+\beta_{4} \text { IntCov }_{i, t}+\beta_{5} \mathrm{ESG} \\
& \text { perform }_{i t}+\beta_{6} \mathrm{ESG}_{\text {-disclose }}{ }_{i t}+\beta_{7} \mathrm{ESG}_{\text {-perform }}{ }_{i t} \mathrm{ESG} \\
& \text { disclose }_{i t}+\beta_{8} \text { Stake }_{i, t}+\beta_{9} \text { YearFixedEffect }_{t}+ \\
& \beta_{10 \text { IndustryFixedEffect }_{i}+v_{i, t}}
\end{aligned}
$$

Consistent with $\mathrm{H}_{2}$, Table 4 (column 3) shows a significant effect of the ESG disclosure on the relationship between ESG performance and the cost of debt. The coefficient of ESG-perform*ESG-disclose is significantly positive, albeit only at the $10 \%$ level $\left(\beta=0.023^{*}\right)$. This suggests the existence of a substitution relationship between ESG performance and disclosure. More specifically, the ESG disclosure acts as a substitute for ESG performance and, therefore, compensate for low ESG performance suggesting that firms with low ESG performance tend to increase ESG disclosure to gain the benefits associated with ESG practices, e.g., lower cost of debt. This result is consistent with the notion that ESG disclosure is used by firms to enhance their reputation and to gain the benefits associated with ESG disclosure (Brown and Deegan, 1998; Cho and Patten, 2007; Dhaliwal et al., 2011b; Li et al., 2018). This finding is also consistent with Fatemi et al. (2017) who find that firms with ESG concerns benefit from ESG-related disclosure; however, it is contradictory to Gao et al. (2016) 
who document a negative association between corporate social responsibility disclosures and the cost of debt only when corporate social responsibility performance is high. ${ }^{10}$

\subsection{The moderating effect of country sustainability characteristics}

To test our third hypothesis that country sustainability characteristics have a positive moderating effect on the relationship between both ESG performance and disclosure and the cost of debt, we include two-level interaction terms between stakeholder orientation (Stake) and both ESG performances and disclosure in our main regression. This interaction term captures the difference in the effects of ESG performance and disclosure on the cost of debt between those countries with greater or lower stakeholder orientation. Thus, we expect the impact of ESG practices on the cost of debt to be greater in countries that are more stakeholderoriented.

$$
\begin{aligned}
\text { CoD }_{i, t}= & \alpha+\beta_{1} \text { Size }_{i, t}+\beta_{2} \text { LEV }_{i, t}+\beta_{3} \text { ROA }_{i, t}+\beta_{4} \text { IntCov }_{i, t}+\beta_{5} \text { ESG }_{i t}^{k}+ \\
& \beta_{6} \text { Stake }_{i, t}+\beta_{7} \text { ESG }_{i t}{ }_{i t} \text { Stake }_{i, t}+\beta_{8} \text { YearFixedEffect }_{t}+ \\
& \beta_{9} \text { IndustryFixedEffect }_{i}+v_{i, t}
\end{aligned}
$$

Columns 4 and 5 in Table 4 show a significant effect of Stake on the relationship between both ESG-perform and ESG-disclose and the cost of debt. The two coefficients of the interaction are significant at $1 \%$ and $5 \%$ respectively $\left(\beta=-0.015^{* * *}, \beta=-0.023^{* * *}\right)$ suggesting that the impact of ESG performance and disclosure on the cost of debt are more obvious in countries that are more stakeholder-oriented. Thus, we accept the third hypothesis $\left(\mathrm{H}_{3}\right)$. In this regard, the coefficient of ESG-perform*ESG-disclose is significantly positive, at the $10 \%$ level ( $\beta=$ $0.021^{*}$ ) in column (4) and insignificantly positive in column (5). This supports the previous finding of a substitution relationship between ESG performance and ESG disclosure. These findings are in line with previous studies in that the variation in the benefits associated with ESG performance and disclosure, in the form of a lower cost of debt, is determined by the country sustainability characteristics (Ball et al., 2000; Ahmed et al., 2013; Christensen et al., 2016; Capelle-Blancard et al., 2016). For instance, Ioannou and Serafeim (2012) find that

\footnotetext{
${ }^{10} \mathrm{Goa}$ et al. (2015) used a sample of all public companies in the Netherlands and examined only corporate social responsibility, while our study addresses ESG practices using cross-country sample.
} 
country-level institutions drive social and environmental performance. Our study extends this to show that variations in the benefits associated with ESG performance and disclosure can be attributed to variation in the country sustainability characteristics. These findings are also consistent with institutional theory, in that organisations are embedded within broader social structures that influence both corporations' decisions as well as stakeholders' perceptions of ESG practices (Campbell, 2007; Aguilera et al., 2007; Jackson and Apostolakou, 2010).

\subsection{Robustness tests}

In this section, we report sensitivity tests that have been performed to examine whether our primary evidence on the association between ESG practices and the cost of debt is robust to alternative assumptions and model specifications. Overall, the results from these sensitivity tests are not quantitatively different from those of the primary analysis. First, we specify, in the main analysis, our dependent variable as the cost of debt, which is measured as the ratio of a firm's interest expense to its average total debt. As an alternative proxy, we use credit ratings ${ }^{11}$ instead of a firm's interest rate as a measure of its cost of debt (Ge and Liu, 2015; Oikonomou et al., 2014; Devalle et al., 2017). We find a significant positive association between ESG performance and the credit ratings, which is consistent with the findings of the main analysis. However, we show that this relationship is stronger in the presence of ESG disclosure. Results are reported in Table 6.

\section{[Insert Table 6 here]}

Secondly, similar to related ESG studies, one concern in relation to the analysis is the potential endogeneity and omitted variables bias, which may diminish the interpretation of the causal relationship between ESG and the cost of debt. For instance, although we control for important variables that affect the cost of debt, the evidence on the importance of ESG to debt pricing might be driven by omitted variables that are correlated with both ESG and the cost of debt. Also, a firm's choice regarding whether to engage in ESG activities might not be independent of its cost of debt, in which case our analysis may be subject to reverse causality concerns (See

\footnotetext{
${ }^{11}$ Credit rating variable has been collected from the Thomson Reuters Asset4 database which is based on Fitch Rating: (AAA (24 points); AA+ (23 points); AA (22 points); AA- (21 points); A+ (20 points); A (19 points); A(18 points); $\mathrm{BBB}+(17$ points); $\mathrm{BBB}$ (16 points); BBB- (15 points); $\mathrm{BB}+(14$ points); $\mathrm{BB}$ (13 points); BB- (12 points); $\mathrm{B}+(11$ points); $\mathrm{B}$ (10 points); $\mathrm{B}-(9$ points $) ; \mathrm{CCC}+(8$ points $) ; \mathrm{CCC}$ (7 points); CCC- (6 points); $\mathrm{CC}+(5$ points); CC (4 points); CC- (3 points); C (2 points); D (1 points); DD (1 points); DDD (1 points)). Then all values are divided by 24 to rank all values between 0 to 1 .
} 
Waddock and Graves, 1997). In particular, two approaches are used to ensure the robustness of our results to endogeneity and reverse causality concerns. First, we employ the instrumental variables estimation method to the main model. We use the industry average scores of ESG performance and disclosure, and a dummy variable for whether the previous year's earnings is negative (loss) as instrumental variables for ESG performance and disclosure ratings. Also, to mitigate the issue of reverse causality (i.e., the cost of debt in the previous period affects current ESG investment), we follow El Ghoul et al. (2011) and Chen et al. (2011) and include the lagged cost of debt as an independent variable. This dynamic panel model is estimated using the system GMM technique developed in Blundell and Bond (1998). In both of these tests, the results indicate that endogeneity concerns are not likely to be driving our primary evidence. Results are reported in Table 7.

Third, our sample shows a high representation of UK firms, which is a common characteristic of sample distributions in most of the EU-based studies (e.g., Daske et al., 2008; Aharony et al., 2010; Byard et al., 2011; Glaum et al., 2013). To ensure the robustness of the findings, we regress the main models after excluding the UK firms from the sample, and the findings remain the same. Results are reported in Table 8.

Fourthly, we use panel regressions with fixed and random effects for the cost of debt. Based on the Hausman test, it is found that the fixed-effects model is more appropriate than the random-effects model. Based on the fixed-effects model, there is a significant negative association between both ESG performance and disclosure and the cost of debt. Also, we find a significant effect of the ESG disclosure on the relationship between ESG performance and the cost of debt, which is consistent with the findings of the main test. However, we find no significant effect of Stake on the relationship between both ESG-perform and ESG-disclose and the cost of debt. Results are reported in Table 9.

Fifthly, based on La Porta et al. (1997), we classify all 15 EU countries into two groups; the code-law countries and common-law countries and run the main tests (results not reported). We find, in general, firms in code-law countries have a significantly lower cost of debt than firms in common-law countries. However, we find no significant difference between both types of countries in terms of the strength of the association between the cost of debt and ESG performance and disclosure (results not reported). 
Finally, we investigate whether the cost of debt reaction to firms' ESG performance and disclosure is a function of its default risk by regressing the same model after adding a dummy variable of default risk (based on the size of the leverage (i.e. above median and below median)) and its interaction with ESG performance and disclosure. In this regard, prior studies employ leverage to control for default risk (e.g., Baker et al., 2003; Verwijmeren and Derwall, 2010; Sun and Cui, 2014; Cheng et al., 2014). For example, Baker et al. (2003) find that firms with high leverage are less capable of obtaining more debt financing because the probability of default is already high. Likewise, Verwijmeren and Derwall (2010) document that firms reduce the probability of default risk and bankruptcy by operating with lower debt ratios. Also, Sun and Cui (2014) find that firm's leverage is positively related to default risk. We find that both ESG performance and disclosure have significant associations with the cost of debt in both types of firms. However, this association is weaker in default risk firms (results not reported).

\section{[Insert Table 7 here]}

[Insert Table 8 here]

[Insert Table 9 here]

\section{Conclusions}

The primary aim of this paper is to gain a deeper understanding of the consequences of ESG performance and its related disclosures that occur in the context of the European Union. Based on the legitimacy and institutional theories, there are three objectives of this paper. Firstly, we address whether lending institutions can interfere in the relationship between firms, state and the community to motivate firms to improve their ESG performance and its related disclosures. Specifically, we examine whether lending institutions reward firms in $15 \mathrm{EU}$ countries for their ESG performance and disclosure in the form of lowering their cost of debt capital. Secondly, given that, the social accounting literature links ESG disclosures to the symbolic approach (e.g., Patten, 2002; Cho and Patten, 2007; Milne and Gray, 2013), we investigate whether lending institutions will distinguish between ESG performance and disclosures (substantive versus symbolic approaches) as part of their lending decision. Thirdly, building on institutional theory, we address the role of the state and community in shaping the effects of ESG performance and disclosures on the lending decision model. 
Using a sample of 6,018 firm-year observations, our findings suggest that firms can benefit from increasing the level of ESG performance and disclosure, which in turn are translated into a lower cost of capital charged by lending institutions. These findings imply that market forces, represented by lending institutions, can initially play a role in improving the relevance and credibility of ESG performance and disclosure and impact sustainable development. Nevertheless, our finding also documented that not only does ESG disclosure have an equal impact on the cost of debt, but also acts as a substitute for ESG performance. Thus, although market forces in the context, represented by decisions and practices of lending institutions, lead to relatively desirable social outcomes through rewarding ESG performance and disclosures, there is a failure to distinguish between ESG performance and disclosure (substantive and symbolic approaches).

Moreover, we find that stakeholder orientation at a country level (consistent with a more community orientated approach) shapes the effects of ESG disclosure and practices on the cost of debt. In particular, the reported evidence suggests that the impact of ESG practices on the cost of debt is more dominant in stakeholder-oriented countries (where community is more prevalent). This, in turn, suggests that ESG practices may be appropriately assessed by civil society as a potential agent for securing change in business behaviour (Deegan, 2017). These findings also reflect upon the importance of the role that the civil society and the state play in addressing and exploring the limitations of free-market regimes. For instance, Maignan (2001) documented that French and German consumers are relatively more concerned about firms conforming to legal and ethical standards than U.S. consumers who instead give greater weighting to the narrower appreciation of corporate economic responsibilities. In line with this, our findings suggest that the market lead to more desired social outcomes (i.e. rewarding ESG practices by lowering cost of debt) when firms belong to a country in which stakeholder groups such as employees, consumers, the government, and communities are likely to have a greater influence on firms' operational decisions.

The results of our study have academic and practical implications. Our findings support the idea of complementary roles between market, state and communities. Our findings suggest that the market play a role in motivating ESG practices by firms (i.e. by rewarding ESG performance and its related disclosures). They also documented that the rewarding of ESG 
performance and disclosure is higher when the state and community, as measured by the level of stakeholder orientation is more prevalent. This, in turn, implies that the state and community reinforce the role of the 'free market' through demand from social constituents, sanctions and boycott or mandatory requirements by the government. Thus, our findings should be of interest to regulators and policymakers, who are considering mandating ESG practices in their respective contexts.

Although this study sheds new light on the association between ESG practices and the cost of debt, it has a number of limitations that represent avenues for future research. First, this study employed secondary data obtained from specialised databases (Thomson Reuters Asset4, Bloomberg, and Thomson Reuters DataStream). Although these databases are widely accepted in management and accounting literature, collecting primary data would strongly support our findings. For example, interviewing CEOs of lending institutions in European countries on the lending decision process, and developing an index for measuring ESG practices manually. Furthermore, our research findings on the association between ESG practices and the cost of debt might be dependent upon the measures of ESG practices we employed. Therefore, the choice of how to measure ESG practices and how it impacts the economic consequences of ESG practices represents an avenue for future research. Second, we use the ratio of a firm's interest expense to its average debt as an accounting measure of the cost of debt, which could be noisy if a firm changes its level of debt near year-end. Although we use credit rating as a robust measure of the cost of debt, future research can employ or develop enhanced measures of the cost of debt to overcome this limitation. Finally, our study focuses on non-financial listed firms in 15 countries in the EU; it would be interesting for future research to expand the sample to include countries with emerging economies and diverse cultural and different institutional settings to investigate whether it will impact the association between ESG practices and the cost of debt. 


\section{References}

Aguilera, R. V., Rupp, D. E., Williams, C. A. \& Ganapathi, J. (2007) Putting the S back in corporate social responsibility: A multilevel theory of social change in organizations. Academy of Management Review, 32(3), 836-863.

Aharony, J., Barniv, R. \& Falk, H. (2010) The impact of mandatory IFRS adoption on equity valuation of accounting numbers for security investors in the EU. European Accounting Review, 19(3), 535-578.

Ahmed, A. S., Neel, M. \& Wang, D. (2013) Does mandatory adoption of IFRS improve accounting quality? Preliminary evidence. Contemporary Accounting Research, 30(4), 1344-1372.

Ahmed, S. \& Uddin, S. (2018) Toward a political economy of corporate governance change and stability in family business groups: A morphogenetic approach. Accounting, Auditing \& Accountability Journal, 31(8), 2192-2217.

Al-Tuwaijri, S. A., Christensen, T. E. \& Hughes Ii, K. (2004) The relations among environmental disclosure, environmental performance, and economic performance: a simultaneous equations approach. Accounting, Organizations and Society, 29(5-6), 447471.

Aman, H. \& Nguyen, P. (2013) Does good governance matter to debtholders? Evidence from the credit ratings of Japanese firms. Research in International Business and Finance, 29, 14-34.

Andrade, S. C., Bernile, G. \& Hood III, F. M. (2014) SOX, corporate transparency, and the cost of debt. Journal of Banking \& Finance, 38, 145-165.

Aragón-Correa, J. A. (1998) Strategic proactivity and firm approach to the natural environment. Academy of Management Journal, 41(5), 556-567.

Arena, M. P. (2018) Corporate litigation and debt. Journal of Banking \& Finance, 87, 202-215.

Ashbaugh-Skaife, H., Collins, D. W. \& LaFond, R. (2006) The effects of corporate governance on firms' credit ratings. Journal of Accounting and Economics, 42(1), 203-243.

Ashforth, B. E. \& Gibbs, B. W. (1990) The double-edge of organizational legitimation. Organization science, 1(2), 177-194.

Baker, M., Stein, J. C. \& Wurgler, J. (2003) When does the market matter? Stock prices and the investment of equity-dependent firms. The Quarterly Journal of Economics, 118(3), 969-1005.

Baldini, M., Dal Maso, L., Liberatore, G., Mazzi, F. \& Terzani, S. (2016) Role of country-and firm-level determinants in environmental, social, and governance disclosure. Journal of Business Ethics, 1-20.

Baldini, M., Dal Maso, L., Liberatore, G., Mazzi, F. \& Terzani, S. (2018) Role of country-and firm-level determinants in environmental, social, and governance disclosure. Journal of Business Ethics, 150(1), 79-98.

Ball, A. \& Craig, R. (2010) Using neo-institutionalism to advance social and environmental accounting. Critical Perspectives on Accounting, 21(4), 283-293.

Ball, R. (2006) International Financial Reporting Standards (IFRS): Pros and cons for investors. Accounting and Business Research, 36(supplement), 5-27.

Ball, R., Kothari, S. \& Robin, A. (2000) The effect of international institutional factors on properties of accounting earnings. Journal of Accounting and Economics, 29(1), 1-51.

Bauer, R. \& Hann, D. (2010) Corporate environmental management and credit risk. Working Paper [Online]. Available: SSRN: https://ssrn.com/abstract $=1660470$ [Accessed 05/09/2018]. 
Belal, A. R., Cooper, S. M. \& Khan, N. A. (2015) Corporate environmental responsibility and accountability: What chance in vulnerable Bangladesh? Critical Perspectives on Accounting, 33, 44-58.

Birindelli, G., Ferretti, P., Intonti, M. \& Iannuzzi, A. P. (2015) On the drivers of corporate social responsibility in banks: evidence from an ethical rating model. Journal of Management \& Governance, 19(2), 303-340.

Brown, N. \& Deegan, C. (1998) The public disclosure of environmental performance information - a dual test of media agenda setting theory and legitimacy theory. Accounting and Business Research, 29(1), 21-41.

Brunsson, N. (2007) The Consequences of Decision-Making. Oxford: Oxford University Press.

Burritt, R. L. \& Schaltegger, S. (2010) Sustainability accounting and reporting: fad or trend? Accounting, Auditing \& Accountability Journal, 23(7), 829-846.

Byard, D., Li, Y.\& Yu, Y. (2011) The effect of mandatory IFRS adoption on financial analysts' information environment. Journal of Accounting Research, 49(1), 69-96.

Cahan, S. F., De Villiers, C., Jeter, D. C., Naiker, V. \& Van Staden, C. J. (2016) Are CSR disclosures value relevant? Cross-country evidence. European Accounting Review, 25(3), 579-611.

Campbell, J. L. (2007) Why would corporations behave in socially responsible ways? An institutional theory of corporate social responsibility. Academy of Management Review, 32(3), 946-967.

Capelle-Blancard, G., Crifo, P., Diaye, M. A., Scholtens, B. \& Oueghlissi, R. (2016) Environmental, Social and Governance (ESG) performance and sovereign bond spreads: an empirical analysis of OECD countries. Working Paper [Online]. Available: SSRN: https://ssrn.com/abstract=2874262 [Accessed 01/02/2018].

Chen, K. C., Chen, Z. \& Wei, K. J. (2011) Agency costs of free cash flow and the effect of shareholder rights on the implied cost of equity capital. Journal of Financial and Quantitative analysis, 46(1), 171-207.

Cheng, B., Ioannou, I. \& Serafeim, G. (2014) Corporate social responsibility and access to finance. Strategic Management Journal, 35(1), 1-23.

Cho, C. H., Guidry, R. P., Hageman, A. M. \& Patten, D. M. (2012a) Do actions speak louder than words? An empirical investigation of corporate environmental reputation. Accounting, Organizations and Society, 37(1), 14-25.

Cho, C. H., Laine, M., Roberts, R. W. \& Rodrigue, M. (2015) Organized hypocrisy, organizational façades, and sustainability reporting. Accounting, Organizations and Society, 40, 78-94.

Cho, C. H., Michelon, G. \& Patten, D. M. (2012b) Impression management in sustainability reports: An empirical investigation of the use of graphs. Accounting and the Public Interest, 12(1), 16-37.

Cho, C. H. \& Patten, D. M. (2007) The role of environmental disclosures as tools of legitimacy: A research note. Accounting, Organizations and Society, 32(7-8), 639-647.

Christensen, H. B., Hail, L. \& Leuz, C. (2016) Capital-market effects of securities regulation: prior conditions, implementation, and enforcement. The Review of Financial Studies, 29(11), 2885-2924.

Clarkson, P. M., Li, Y., Richardson, G. D. \& Vasvari, F. P. (2008) Revisiting the relation between environmental performance and environmental disclosure: An empirical analysis. Accounting, organizations and society, 33(4-5), 303-327. 
Cormier, D. \& Magnan, M. (2007) The revisited contribution of environmental reporting to investors' valuation of a firm's earnings: An international perspective. Ecological economics, 62(3-4), 613-626.

Crifo, P., Diaye, M.-A. \& Oueghlissi, R. (2017) The effect of countries' ESG ratings on their sovereign borrowing costs. The Quarterly Review of Economics and Finance, 66, 13-20.

Cui, J., Jo, H. \& Na, H. (2018) Does corporate social responsibility affect information asymmetry? Journal of Business Ethics, 148(3), 549-572.

Daske, H., Hail, L., Leuz, C. \& Verdi, R. (2008) Mandatory IFRS reporting around the world: Early evidence on the economic consequences. Journal of Accounting Research, 46(5), $1085-1142$.

Deegan, C. (2010) Organizational legitimacy as a motive for sustainability reporting. Sustainability accounting and accountability. Routledge.

Deegan, C. (2017) Twenty five years of social and environmental accounting research within Critical Perspectives of Accounting: Hits, misses and ways forward. Critical Perspectives on Accounting, 43, 65-87.

Deegan, C. \& Shelly, M. (2014) Corporate social responsibilities: Alternative perspectives about the need to legislate. Journal of Business Ethics, 121(4), 499-526.

Deegan, C. \& Unerman, J. (2011) Financial accounting theory (2nd ed.). Maidenhead, Berkshire: McGraw Hill Education.

Deephouse, D. L. (1996) Does isomorphism legitimate? Academy of management journal, 39(4), 1024-1039.

Dennis, S. A. \& Mullineaux, D. J. (2000) Syndicated loans. Journal of Financial Intermediation, 9(4), 404-426.

Devalle, A., Fiandrino, S. \& Cantino, V. (2017) The Linkage between ESG Performance and Credit Ratings: A Firm-Level Perspective Analysis. International Journal of Business and Management, 12(9), 53.

Dhaliwal, D., Hogan, C., Trezevant, R. \& Wilkins, M. (2011a) Internal control disclosures, monitoring, and the cost of debt. The Accounting Review, 86(4), 1131-1156.

Dhaliwal, D., Li, O. Z., Tsang, A. \& Yang, Y. G. (2014) Corporate social responsibility disclosure and the cost of equity capital: The roles of stakeholder orientation and financial transparency. Journal of Accounting and Public Policy, 33(4), 328-355.

Dhaliwal, D. S., Li, O. Z., Tsang, A. \& Yang, Y. G. (2011b) Voluntary nonfinancial disclosure and the cost of equity capital: The initiation of corporate social responsibility reporting. The Accounting Review, 86(1), 59-100.

Dhaliwal, D. S., Radhakrishnan, S., Tsang, A. \& Yang, Y. G. (2012) Nonfinancial disclosure and analyst forecast accuracy: International evidence on corporate social responsibility disclosure. The Accounting Review, 87(3), 723-759.

DiMaggio, P. J. \& Powell, W. W. (1983) The iron cage revisited: Institutional isomorphism and collective rationality in organizational fields. American sociological review, 147160 .

Donaldson, T. \& Preston, L. E. (1995) The stakeholder theory of the corporation: Concepts, evidence, and implications. Academy of Management Review, 20(1), 65-91.

El Ghoul, S., Guedhami, O., Kwok, C. C. \& Mishra, D. R. (2011) Does corporate social responsibility affect the cost of capital? Journal of Banking \& Finance, 35(9), 2388-2406.

Erragragui, E. (2017) Do creditors price firms' environmental, social and governance risks? Research in International Business and Finance, 45, 197-207.

Fatemi, A., Glaum, M. \& Kaiser, S. (2017) ESG performance and firm value: The moderating role of disclosure. Global Finance Journal, Forthcoming. 
Florou, A. \& Kosi, U. (2015) Does mandatory IFRS adoption facilitate debt financing? Review of Accounting Studies, 20(4), 1407-1456.

Francis, J., LaFond, R., Olsson, P. \& Schipper, K. (2005) The market pricing of accruals quality. Journal of Accounting and Economics, 39(2), 295-327.

Freeman, R. (1984) Strategic Management: A Stakeholder Approach. London: Pitman Publishing.

Gao, F., Dong, Y., Ni, C. \& Fu, R. (2016) Determinants and economic consequences of nonfinancial disclosure quality. European Accounting Review, 25(2), 287-317.

Ge, W. \& Liu, M. (2015) Corporate social responsibility and the cost of corporate bonds. Journal of Accounting and Public Policy, 34(6), 597-624.

Glaum, M., Schmidt, P., Street, D. L. \& Vogel, S. (2013) Compliance with IFRS 3-and IAS 36-required disclosures across 17 European countries: company-and country-level determinants. Accounting and Business Research, 43(3), 163-204.

Goh, B. W., Lee, J., Lim, C. Y. \& Shevlin, T. (2016) The effect of corporate tax avoidance on the cost of equity. The Accounting Review, 91(6), 1647-1670.

Goss, A. \& Roberts, G. S. (2011) The impact of corporate social responsibility on the cost of bank loans. Journal of Banking \& Finance, 35(7), 1794-1810.

Gray, P., Koh, P. S. \& Tong, Y. H. (2009) Accruals quality, information risk and cost of capital: Evidence from Australia. Journal of Business Finance \& Accounting, 36(1-2), 51-72.

Gray, R. (2010) Is accounting for sustainability actually accounting for sustainability... and how would we know? An exploration of narratives of organisations and the planet. Accounting, organizations and society, 35(1), 47-62.

Gray, R., Kouhy, R. \& Lavers, S. (1995) Corporate social and environmental reporting: a review of the literature and a longitudinal study of UK disclosure. Accounting, Auditing \& Accountability Journal, 8(2), 47-77.

Hart, S. L. (1995) A natural-resource-based view of the firm. Academy of Management Review, 20(4), 986-1014.

Hasan, I., Hoi, C. K., Wu, Q. \& Zhang, H. (2017) Social capital and debt contracting: Evidence from bank loans and public bonds. Journal of Financial and Quantitative Analysis, 52(3), 1017-1047.

Hemingway, C. A. \& Maclagan, P. W. (2004) Managers' personal values as drivers of corporate social responsibility. Journal of Business Ethics, 50(1), 33-44.

Hillman, A. J. \& Keim, G. D. (2001) Shareholder value, stakeholder management, and social issues: what's the bottom line? Strategic Management Journal, 22(2), 125-139.

Hoepner, A., Oikonomou, I., Scholtens, B. \& Schröder, M. (2016) The effects of corporate and country sustainability characteristics on the cost of debt: an international investigation. Journal of Business Finance \& Accounting, 43(1-2), 158-190.

Hopwood, A. G. (2009) Accounting and the environment. Accounting, organizations and society, 34(3-4), 433-439.

Houqe, M. N., Easton, S. \& van Zijl, T. (2014) Does mandatory IFRS adoption improve information quality in low investor protection countries? Journal of International Accounting, Auditing and Taxation, 23(2), 87-97.

Huber, B. M. \& Comstock, M. (2017) ESG reports and ratings: What they Are, why they matter. The Corporate Governance Advisor, 25(5), 1-12.

Hughes, S. B., Anderson, A. \& Golden, S. (2001) Corporate environmental disclosures: are they useful in determining environmental performance? Journal of Accounting and Public Policy, 20(3), 217-240. 
Husillos, J., González, C. L. \& Gil, M. J. Á. (2011) The emergence of triple bottom line reporting in Spain. Spanish Journal of Finance and Accounting/Revista Española de Financiación y Contabilidad, 40(150), 195-219.

Ioannou, I. \& Serafeim, G. (2012) What drives corporate social performance? The role of nation-level institutions. Journal of International Business Studies, 43(9), 834-864.

Jackson, G. \& Apostolakou, A. (2010) Corporate social responsibility in Western Europe: an institutional mirror or substitute? Journal of Business Ethics, 94(3), 371-394.

Jensen, M. C. \& Smith, C. W. (1985) Stockholder, manager, and creditor interests: Applications of agency theory. Working Paper [Online]. Available: SSRN: http://dx.doi.org/10.2139/ssrn.173461 [Accessed 24/02/2018].

Jo, H. \& Harjoto, M. A. (2011) Corporate governance and firm value: The impact of corporate social responsibility. Journal of Business Ethics, 103(3), 351-383.

Jones, T. M. (1995) Instrumental stakeholder theory: A synthesis of ethics and economics. Academy of Management Review, 20(2), 404-437.

Jung, J., Herbohn, K. \& Clarkson, P. (2016) Carbon risk, carbon risk awareness and the cost of debt financing. Journal of Business Ethics, 1-21.

Jung, J., Herbohn, K. \& Clarkson, P. (2018) Carbon risk, carbon risk awareness and the cost of debt financing. Journal of Business Ethics, 150(4), 1151-1171.

Kim, E.-H. \& Lyon, T. P. (2014) Greenwash vs. brownwash: Exaggeration and undue modesty in corporate sustainability disclosure. Organization Science, 26(3), 705-723.

Kitson, A. (1996) Taking the pulse: Ethics and the British cooperative bank. Journal of Business Ethics, 15(9), 1021-1031.

Kolk, A., Levy, D. \& Pinkse, J. (2008) Corporate responses in an emerging climate regime: The institutionalization and commensuration of carbon disclosure. European Accounting Review, 17(4), 719-745.

La Porta, R., Lopez-de-Silanes, F., Shleifer, A. \& Vishny, R. W. (1997) Legal determinants of external finance. The Journal of Finance, 1131-1150.

Leuz, C. (2010) Different approaches to corporate reporting regulation: How jurisdictions differ and why. Accounting and Business Research, 40(3), 229-256.

Levitt, T. (1958) The dangers of social-responsibility. Harvard business review, 36(5), 41-50.

Lewis, L. \& Unerman, J. (1999) Ethical relativism: a reason for differences in corporate social reporting? Critical Perspectives on Accounting, 10(4), 521-547.

Li, S. (2010) Does mandatory adoption of International Financial Reporting Standards in the European Union reduce the cost of equity capital? The Accounting Review, 85(2), 607636.

Li, Y., Gong, M., Zhang, X.-Y. \& Koh, L. (2018) The impact of environmental, social, and governance disclosure on firm value: The role of CEO power. The British Accounting Review, 50(1), 60-75.

Lyon, T. P. \& Maxwell, J. W. (2011) Greenwash: Corporate environmental disclosure under threat of audit. Journal of Economics \& Management Strategy, 20(1), 3-41.

Maignan, I. (2001) Consumers' perceptions of corporate social responsibilities: A crosscultural comparison. Journal of business ethics, 30(1), 57-72.

Manganaris, P., Spathis, C. \& Dasilas, A. (2015) The effects of mandatory IFRS adoption and conditional conservatism on European bank values. Journal of International Accounting, Auditing and Taxation, 24, 72-81.

Matten, D. \& Moon, J. (2008) "Implicit" and "explicit" CSR: A conceptual framework for a comparative understanding of corporate social responsibility. Academy of management Review, 33(2), 404-424. 
Mattingly, J. E. (2017) Corporate social performance: A review of empirical research examining the corporation-society relationship using Kinder, Lydenberg, Domini Social Ratings data. Business \& Society, 56(6), 796-839.

Merkl-Davies, D. M. \& Brennan, N. M. (2007) Discretionary disclosure strategies in corporate narratives: incremental information or impression management?

Michelon, G., Pilonato, S. \& Ricceri, F. (2015) CSR reporting practices and the quality of disclosure: An empirical analysis. Critical Perspectives on Accounting, 33, 59-78.

Michelon, G., Pilonato, S., Ricceri, F. \& Roberts, R. W. (2016) Behind camouflaging: traditional and innovative theoretical perspectives in social and environmental accounting research. Sustainability Accounting, Management and Policy Journal, 7(1), $2-25$.

Milne, M. J. \& Gray, R. (2013) W (h) ither ecology? The triple bottom line, the global reporting initiative, and corporate sustainability reporting. Journal of business ethics, 118(1), 1329.

Mitchell, R. K., Agle, B. R. \& Wood, D. J. (1997) Toward a theory of stakeholder identification and salience: Defining the principle of who and what really counts. Academy of Management Review, 22(4), 853-886.

Moneva, J. M., Archel, P. \& Correa, C. (Year) GRI and the camouflaging of corporate unsustainability. In: Accounting forum, 2006. Taylor \& Francis, 121-137.

Moscariello, N., Skerratt, L. \& Pizzo, M. (2014) Mandatory IFRS adoption and the cost of debt in Italy and UK. Accounting and Business Research, 44(1), 63-82.

Moser, D. V. \& Martin, P. R. (2012) A broader perspective on corporate social responsibility research in accounting. The Accounting Review, 87(3), 797-806.

Nandy, M. \& Lodh, S. (2012) Do banks value the eco-friendliness of firms in their corporate lending decision? Some empirical evidence. International Review of Financial Analysis, 25, 83-93.

Nazari, J. A., Hrazdil, K. \& Mahmoudian, F. (2017) Assessing social and environmental performance through narrative complexity in CSR reports. Journal of Contemporary Accounting \& Economics, 13(2), 166-178.

Neu, D., Warsame, H. \& Pedwell, K. (1998) Managing public impressions: environmental disclosures in annual reports. Accounting, organizations and society, 23(3), 265-282.

Newey, W. K. \& West, K. D. (1987) A simple, positive semi-definite, heteroskedasticity and autocorrelation consistent covariance matrix. Econometrica: Journal of the Econometric Society, 55(3), 703-708.

Oikonomou, I., Brooks, C. \& Pavelin, S. (2014) The effects of corporate social performance on the cost of corporate debt and credit ratings. Financial Review, 49(1), 49-75.

Orlitzky, M., Schmidt, F. L. \& Rynes, S. L. (2003) Corporate social and financial performance: A meta-analysis. Organization Studies, 24(3), 403-441.

Owen, D. L., Swift, T. A., Humphrey, C. \& Bowerman, M. (2000) The new social audits: accountability, managerial capture or the agenda of social champions? European Accounting Review, 9(1), 81-98.

Patten, D. M. (2002) The relation between environmental performance and environmental disclosure: a research note. Accounting, organizations and Society, 27(8), 763-773.

Rahaman, M. M. \& Al Zaman, A. (2013) Management quality and the cost of debt: Does management matter to lenders? Journal of Banking \& Finance, 37(3), 854-874.

Russo, M. V. \& Fouts, P. A. (1997) A resource-based perspective on corporate environmental performance and profitability. Academy of Management Journal, 40(3), 534-559. 
Scholtens, B. (2006) Finance as a driver of corporate social responsibility. Journal of Business Ethics, 68(1), 19-33.

Scholtens, B. (2009) Corporate social responsibility in the international banking industry. Journal of Business Ethics, 86(2), 159-175.

Shrivastava, P. (1995) Ecocentric management for a risk society. Academy of Management Review, 20(1), 118-137.

Spence, C., Husillos, J. \& Correa-Ruiz, C. (2010) Cargo cult science and the death of politics: A critical review of social and environmental accounting research. Critical Perspectives on Accounting, 21(1), 76-89.

SSE. (2015) Model Guidance on Reporting ESG Information to Investors,. Available: http://www.sseinitiative.org/wp-content/uploads/2015/10/SSE-Model-Guidance-onReporting-ESG.pdf [Accessed 15/03/2018].

Stellner, C., Klein, C. \& Zwergel, B. (2015) Corporate social responsibility and Eurozone corporate bonds: The moderating role of country sustainability. Journal of Banking \& Finance, 59, 538-549.

Streeck, W. \& Schmitter, P. (1985) Private Interest Government. Beverly Hills, CA: Sage.

Suchman, M. C. (1995) Managing legitimacy: Strategic and institutional approaches. Academy of management review, 20(3), 571-610.

Sun, W. \& Cui, K. (2014) Linking corporate social responsibility to firm default risk. European Management Journal, 32(2), 275-287.

Thompson, P. \& Cowton, C. J. (2004) Bringing the environment into bank lending: implications for environmental reporting. The British Accounting Review, 36(2), 197218.

Thomson Reuters. (2017) Thomson Reuters ESG Scores. Available: https://financial.thomsonreuters.com/content/dam/openweb/documents/pdf/financial/es g-scores-methodology.pdf [Accessed 05/01/2018].

Tinker, T. \& Neimark, M. (1987) The role of annual reports in gender and class contradictions at General Motors: 1917-1976. Accounting, organizations and society, 12(1), 71-88.

Tran, D. H. (2014) Multiple corporate governance attributes and the cost of capital-Evidence from Germany. The British Accounting Review, 46(2), 179-197.

UNEP. (2012) UNEP Statement of Commitment by Financial Institutions on Sustainable Development. Available: http://www.unepfi.org/about/unep-fi-statement/ [Accessed 01/03/2018].

United Nations. (2016) Agenda 2030: A Window of Opportunity 1,000+ CEOs, 100+ countries, 25+ industries call for greater local collaboration with national governments on SDG Action Plans. Available: www.accenture.com/ungcceostudy [Accessed 20/03/2018].

Verwijmeren, P. \& Derwall, J. (2010) Employee well-being, firm leverage, and bankruptcy risk. Journal of Banking \& Finance, 34(5), 956-964.

Waddock, S. A. \& Graves, S. B. (1997) The corporate social performance-financial performance link. Strategic Management Journal, 18(4), 303-319.

Weber, O., Diaz, M. \& Schwegler, R. (2014) Corporate social responsibility of the financial sector-Strengths, weaknesses and the impact on sustainable development. Sustainable Development, 22(5), 321-335.

Weber, O., Scholz, R. W. \& Michalik, G. (2010) Incorporating sustainability criteria into credit risk management. Business Strategy and the Environment, 19(1), 39-50.

Ye, K. \& Zhang, R. (2011) Do lenders value corporate social responsibility? Evidence from China. Journal of Business Ethics, 104(2), 197. 
Zeidan, R., Boechat, C. \& Fleury, A. (2015) Developing a sustainability credit score system. Journal of Business Ethics, 127(2), 283-296. 
Table 1: Total number of firms per industry and country

Panel A: Total number of firms per industry

\begin{tabular}{|c|c|c|}
\hline Industry & \multicolumn{2}{|c|}{ Total } \\
\hline Basic Materials & 563 & $9.4 \%$ \\
\hline Consumer Goods & 908 & $15.1 \%$ \\
\hline Consumer Services & 1,287 & $21.4 \%$ \\
\hline Health Care & 369 & $6.1 \%$ \\
\hline Industrials & 1,879 & $31.2 \%$ \\
\hline Oil \& Gas & 450 & $7.5 \%$ \\
\hline Technology & 326 & $5.4 \%$ \\
\hline Telecommunications & 236 & $3.9 \%$ \\
\hline Total & 6,018 & $100 \%$ \\
\hline
\end{tabular}

Panel B: Total number of firms per country

\begin{tabular}{|c|c|c|}
\hline Country & \multicolumn{2}{|c|}{ Total } \\
\hline Austria & 81 & $1.3 \%$ \\
Belgium & 161 & $2.7 \%$ \\
Denmark & 214 & $3.6 \%$ \\
Finland & 237 & $3.9 \%$ \\
France & 761 & $12.6 \%$ \\
Germany & 653 & $10.9 \%$ \\
Greece & 109 & $1.8 \%$ \\
Ireland & 132 & $2.2 \%$ \\
Italy & 251 & $4.2 \%$ \\
Netherlands & 203 & $3.4 \%$ \\
Norway & 159 & $2.6 \%$ \\
Portugal & 82 & $1.4 \%$ \\
Spain & 357 & $5.9 \%$ \\
Sweden & 250 & $4.2 \%$ \\
UK & 2,368 & $39.3 \%$ \\
\hline Total & $\mathbf{6 , 0 1 8}$ & $\mathbf{1 0 0 \%}$ \\
\hline
\end{tabular}


Table 2: Descriptive statistics

\begin{tabular}{|l|ccccc|}
\hline Variable & Mean & S.D. & 0.25 & Mdn & 0.75 \\
\hline The cost of debt (CoD) & 0.064 & 0.07 & 0.037 & 0.051 & 0.067 \\
Credit ratings & 0.462 & 0.254 & 0.299 & 0.467 & 0.621 \\
ESG-perform & 0.661 & 0.274 & 0.453 & 0.763 & 0.895 \\
ESG-disclose & 0.359 & 0.142 & 0.248 & 0.355 & 0.469 \\
Environmental-perform & 0.650 & 0.280 & 0.410 & 0.743 & 0.907 \\
Social-perform & 0.672 & 0.261 & 0.486 & 0.750 & 0.901 \\
Governance-perform & 0.595 & 0.260 & 0.403 & 0.651 & 0.817 \\
Environmental-disclose & 0.297 & 0.166 & 0.163 & 0.295 & 0.419 \\
Social-disclose & 0.385 & 0.161 & 0.281 & 0.386 & 0.509 \\
Governance-disclose & 0.527 & 0.114 & 0.464 & 0.536 & 0.607 \\
Stake & 0.93 & 0.887 & 0.47 & 0.47 & 1.12 \\
LEV & 0.252 & 0.172 & 0.128 & 0.238 & 0.351 \\
Size (log of total assets) & 15.02 & 1.47 & 13.99 & 14.93 & 15.93 \\
ROA & 0.0515 & 0.0789 & 0.0205 & 0.0488 & 0.0832 \\
Total Assets (\$ mils) & 11,000 & 25,000 & 1,200 & 3,000 & 8,300 \\
Sales (\$ mils) & 8,300 & 19,000 & 980 & 2,500 & 7,400 \\
\hline
\end{tabular}

The sample consists of 6,018 firm-year observations over the period 2005 to 2016 (8 industries). Appendix A outlines definitions and data sources for all variables.

Table 3: Pearson correlations between CoD, ESG Performance, and ESG disclosure and control variables

\begin{tabular}{|c|c|c|c|c|c|c|c|c|}
\hline & $\mathrm{CoD}$ & $\begin{array}{c}\text { ESG- } \\
\text { perform }\end{array}$ & $\begin{array}{c}\text { ESG- } \\
\text { disclose }\end{array}$ & Stake & $L E V$ & Size & $R O A$ & $\begin{array}{c}\text { IntCo } \\
v\end{array}$ \\
\hline $\mathrm{CoD}$ & 1 & & & & & & & \\
\hline \multirow{3}{*}{ ESG-perform } & -0.1152 & 1 & & & & & & \\
\hline & $\begin{array}{c}<0.000 \\
1\end{array}$ & & & & & & & \\
\hline & -0.1228 & 0.6146 & 1 & & & & & \\
\hline ESG-disclose & $\begin{array}{c}<0.000 \\
1\end{array}$ & $\begin{array}{c}<0.000 \\
1\end{array}$ & & & & & & \\
\hline \multirow[t]{2}{*}{ Stake } & -0.0671 & 0.0647 & 0.0924 & 1 & & & & \\
\hline & $\begin{array}{c}<0.000 \\
1\end{array}$ & $\begin{array}{c}<0.000 \\
1\end{array}$ & $\begin{array}{c}<0.000 \\
1\end{array}$ & & & & & \\
\hline \multirow[t]{2}{*}{$L E V$} & 0.2608 & -0.0081 & 0.0421 & -0.0375 & 1 & & & \\
\hline & $\begin{array}{c}<0.000 \\
1\end{array}$ & 0.4983 & 0.0086 & 0.0018 & & & & \\
\hline \multirow[t]{2}{*}{ Size } & -0.1973 & 0.4914 & 0.5207 & 0.0589 & 0.2203 & 1 & & \\
\hline & $\begin{array}{c}<0.000 \\
1\end{array}$ & $\begin{array}{c}<0.000 \\
1\end{array}$ & $\begin{array}{c}<0.000 \\
1\end{array}$ & $\begin{array}{c}<0.000 \\
1\end{array}$ & $\begin{array}{c}<0.000 \\
1\end{array}$ & & & \\
\hline \multirow[t]{2}{*}{$R O A$} & 0.0675 & 0.011 & -0.1102 & 0.0279 & -0.2589 & -0.1517 & 1 & \\
\hline & $\begin{array}{c}<0.000 \\
1\end{array}$ & 0.3575 & $\begin{array}{c}<0.000 \\
1\end{array}$ & 0.0201 & $\begin{array}{c}<0.000 \\
1\end{array}$ & $\begin{array}{c}<0.000 \\
1\end{array}$ & & \\
\hline IntCov & -0.1482 & -0.0556 & -0.0751 & 0.0191 & -0.3059 & -0.1865 & 0.3368 & 1 \\
\hline
\end{tabular}




\begin{tabular}{|c|ccccccc|}
\hline & $<0.000$ & $<0.000$ & $<0.000$ & \multirow{2}{*}{0.1161} & $<0.000$ & $<0.000$ & $<0.000$ \\
& 1 & 1 & 1 & 1 & 1 & 1 \\
\hline
\end{tabular}

The sample comprises of 6,018 firm-year observations over the period 2005 to 2016. Appendix A outlines definitions and data sources for all variables.

$* * *$ p-value $<0.01, * *$ p-value $<0.05, *$ p-value $<0.1$. Significance levels are shown in italics.

Table 4: Pooled regressions of ESG performance and ESG disclosure on the cost of debt (the interest rate proxy)

\begin{tabular}{|c|c|c|c|c|c|}
\hline & (1) & (2) & (3) & (4) & $(5)$ \\
\hline$L E V$ & $\begin{array}{c}0.096^{* * * *} \\
(16.6)\end{array}$ & $\begin{array}{c}0.095^{* * * *} \\
(12.4)\end{array}$ & $\begin{array}{c}0.096^{* * * *} \\
(13.4)\end{array}$ & $\begin{array}{c}0.091^{* * *} \\
(13.2)\end{array}$ & $\begin{array}{c}0.092^{* * * *} \\
(13.2)\end{array}$ \\
\hline Size & $\begin{array}{c}-0.0068^{* * *} \\
(-8.92)\end{array}$ & $\begin{array}{c}-0.0065^{\text {*** }} \\
(-6.45)\end{array}$ & $\begin{array}{c}-0.0076^{\text {**** }} \\
(-7.76)\end{array}$ & $\begin{array}{c}-0.0065^{\text {**** }} \\
(-6.77)\end{array}$ & $\begin{array}{c}-0.0050^{* * *} \\
(-5.10)\end{array}$ \\
\hline$R O A$ & $\begin{array}{c}-0.034^{* * *} \\
(-2.74)\end{array}$ & $\begin{array}{l}-0.024 \\
(-1.30)\end{array}$ & $\begin{array}{l}-0.036^{* *} \\
(-1.97)\end{array}$ & $\begin{array}{l}-0.014 \\
(-0.79)\end{array}$ & $\begin{array}{l}-0.0085 \\
(-0.48)\end{array}$ \\
\hline IntCov & $\begin{array}{c}-0.000056^{* * * *} \\
(-6.18)\end{array}$ & $\begin{array}{c}-0.000034^{* * *} \\
(-3.49)\end{array}$ & $\begin{array}{c}-0.000033^{* * * *} \\
(-3.42)\end{array}$ & $\begin{array}{c}-0.000028^{* * *} \\
(-2.90)\end{array}$ & $\begin{array}{c}-0.000028^{* * * *} \\
(-2.88)\end{array}$ \\
\hline Stake & $\begin{array}{c}-0.0054^{* * *} \\
(-5.34)\end{array}$ & $\begin{array}{c}-0.0065^{* * *} \\
(-5.41)\end{array}$ & $\begin{array}{c}-0.0061^{* * * *} \\
(-5.23)\end{array}$ & $\begin{array}{l}-0.0052 \\
(-1.22)\end{array}$ & $\begin{array}{l}-0.0026 \\
(-0.82)\end{array}$ \\
\hline ESG-perform & $\begin{array}{c}-0.011^{* * * *} \\
(-2.76)\end{array}$ & & $\begin{array}{c}-0.018^{* * *} \\
(-2.86)\end{array}$ & $\begin{array}{l}-0.0081 \\
(-1.07)\end{array}$ & $\begin{array}{l}-0.0062 \\
(-0.55)\end{array}$ \\
\hline ESG-disclose $e^{(1)}$ & & $\begin{array}{c}-0.024^{* *} \\
(-2.57)\end{array}$ & $\begin{array}{c}-0.00013 \\
(-1.08)\end{array}$ & $\begin{array}{r}-0.0095 \\
(-0.80)\end{array}$ & $\begin{array}{l}-0.019 \\
(-0.56)\end{array}$ \\
\hline $\begin{array}{l}\text { ESG-perform *ESG- } \\
\text { disclose } \\
\text { ESG-perform*Stake }\end{array}$ & & & $\begin{array}{l}0.023^{*} \\
(1.68)\end{array}$ & $\begin{array}{c}0.021^{*} \\
(1.67) \\
-0.015^{* * *} \\
(-2.78)\end{array}$ & $\begin{array}{l}0.011 \\
(0.29)\end{array}$ \\
\hline ESG-disclose* Stake & & & & & $\begin{array}{c}-0.023^{* * * *} \\
(-2.78)\end{array}$ \\
\hline Constant & $\begin{array}{l}0.19^{* * *} \\
(20.1)\end{array}$ & $\begin{array}{l}0.17^{* * *} \\
(12.5)\end{array}$ & $\begin{array}{l}0.24^{* * *} \\
(12.9)\end{array}$ & $\begin{array}{l}0.19^{* * *} \\
(12.8)\end{array}$ & $\begin{array}{l}0.17^{* * *} \\
(9.59)\end{array}$ \\
\hline $\mathrm{N}$ & 6,018 & 3,384 & 3,384 & 3,384 & 3,384 \\
\hline $\operatorname{adj} . R^{2}$ & 0.099 & 0.095 & 0.105 & 0.099 & 0.097 \\
\hline Year dummies & Yes & Yes & Yes & Yes & Yes \\
\hline Industry dummies & Yes & Yes & Yes & Yes & Yes \\
\hline
\end{tabular}

The sample comprises of 6,018 firm-year observations over the period 2005 to 2016. Appendix A outlines definitions and data sources for all variables.

$* * *$ p-value $<0.01, * *$ p-value $<0.05, *$ p-value $<0.1$. $t$-statistics in parentheses and italic.

(1) In column (3) and (4), ESG-disclose variable is measured using a dummy variable that takes the value of one if firms have higher ESG disclosure than the median and zero otherwise. 
Table 5: Pooled regressions of the Environmental, Social and Governance performance and disclosure components on the cost of debt

Panel A: Pooled regressions of the Environmental, Social and Governance Performance Scores on the cost of debt

\begin{tabular}{|l|ccc|}
\hline & $(1)$ & $(2)$ & $(3)$ \\
\hline LEV & $0.098^{* * * *}$ & $0.096^{* * *}$ & $0.095^{* * *}$ \\
& $(17.9)$ & $(17.7)$ & $(17.5)$ \\
Size & $-0.0060^{* * *}$ & $-0.0061^{* * *}$ & $-0.0072^{* * *}$ \\
& $(-8.42)$ & $(-8.52)$ & $(-11.9)$ \\
IntCov & $-0.026^{* *}$ & $-0.025^{* *}$ & $-0.026^{* *}$ \\
& $(-2.11)$ & $(-2.06)$ & $(-2.13)$ \\
Stake & $-0.000048^{* * *}$ & $-0.000049^{* * *}$ & $-0.000049^{* * *}$ \\
& $(-5.29)$ & $(-5.44)$ & $(-5.38)$ \\
Environmental-Perform & $-0.0054^{* * *}$ & $-0.0057^{* * *}$ & $-0.0059^{* * *}$ \\
& $(-5.64)$ & $(-5.93)$ & $(-6.08)$ \\
Social-perform & $-0.012^{* * *}$ & & \\
& $(-3.41)$ & & \\
Governance- perform & & $-0.012^{* * *}$ & \\
& & $(-3.20)$ & \\
Constant & & & -0.00084 \\
& & & $(-0.25)$ \\
$N$ & $0.19^{* * *}$ & $0.19^{* * *}$ & $0.20^{* * *}$ \\
adj. $R^{2}$ & $(19.9)$ & $(20.1)$ & $(22.0)$ \\
\hline Year dummies & 6,018 & 6,018 & 6,018 \\
Industry dummies & 0.104 & 0.104 & 0.103 \\
\hline
\end{tabular}

The sample comprises of 6,018 firm-year observations over the period 2005 to 2016. Appendix A outlines definitions and data sources for all variables.

$* * *$ p-value $<0.01$, ** p-value $<0.05, *$ p-value $<0.1$. $t$-statistics in parentheses and italic 
Panel B: Pooled regressions of the Environmental, Social, Governance Disclosure Scores on the cost of debt

\begin{tabular}{|l|ccc|}
\hline & $(1)$ & $(2)$ & $(3)$ \\
\hline LEV & $0.093^{* * *}$ & $0.093^{* * *}$ & $0.091^{* * *}$ \\
& $(12.7)$ & $(13.2)$ & $(13.0)$ \\
Size & $-0.0057^{* * *}$ & $-0.0061^{* * *}$ & $-0.0059^{* * *}$ \\
& $(-5.87)$ & $(-6.85)$ & $(-7.02)$ \\
IntCov & -0.023 & -0.014 & -0.012 \\
& $(-1.23)$ & $(-0.80)$ & $(-0.67)$ \\
Stake & $-0.000023^{* *}$ & $-0.000019^{*}$ & $-0.000029^{* * *}$ \\
& $(-2.26)$ & $(-1.93)$ & $(-2.96)^{* * *}$ \\
Environmental-disclose & $-0.0061^{* * *}$ & $-0.0065^{* * *}$ & $-0.0061^{* * *}$ \\
& $(-5.10)$ & $(-5.57)$ & $(-5.34)$ \\
Social-disclose & $-0.018^{* *}$ & & \\
& $(-2.41)$ & & \\
Governance-disclose & & $-0.016^{*}$ & \\
& & $(-1.68)$ & \\
Constant & & & $-0.018^{*}$ \\
& & & $(-1.93)$ \\
$N$ & $0.18^{* * *}$ & $0.19^{* * *}$ & $0.19^{* * *}$ \\
adj. $R^{2}$ & $(12.4)$ & $(13.9)$ & $(14.4)$ \\
\hline Year dummies & 3166 & 3292 & 3379 \\
Industry dummies & 0.097 & 0.096 & 0.094 \\
\hline
\end{tabular}

The sample ranges between 3,166 and 3,379 firm-year observations over the period 2005 to 2016. Appendix A outlines definitions and data sources for all variables.

*** $\mathrm{p}$-value $<0.01, * * \mathrm{p}$-value $<0.05, * \mathrm{p}$-value $<0.1$. $t$-statistics in parentheses and italic 
Table 6: Pooled regressions of ESG performance and ESG disclosure on the cost of debt (the credit ratings proxy)

\begin{tabular}{|c|c|c|c|c|c|}
\hline & $(1)$ & (2) & (3) & (4) & $(5)$ \\
\hline$L E V$ & $\begin{array}{l}-0.16^{* * *} \\
(-4.58)\end{array}$ & $\begin{array}{c}-0.22^{* * * *} \\
(-4.92)\end{array}$ & $\begin{array}{c}-0.22^{* * *} \\
(-5.00)\end{array}$ & $\begin{array}{l}-0.16^{* * * *} \\
(-4.37)\end{array}$ & $\begin{array}{l}-0.19^{* * * *} \\
(-4.06)\end{array}$ \\
\hline Size & $\begin{array}{l}0.11^{\text {**** }} \\
(23.2)\end{array}$ & $\begin{array}{l}0.10^{* * * *} \\
(17.5)\end{array}$ & $\begin{array}{c}0.10^{* * *} \\
(17.7)\end{array}$ & $\begin{array}{l}0.11^{* * *} \\
(21.2)\end{array}$ & $\begin{array}{l}0.11^{* * * *} \\
(16.1)\end{array}$ \\
\hline$R O A$ & $\begin{array}{l}0.75^{* * *} \\
(8.36)\end{array}$ & $\begin{array}{l}0.86^{* * * *} \\
(7.12)\end{array}$ & $\begin{array}{l}0.80^{* * * *} \\
(6.60)\end{array}$ & $\begin{array}{l}0.80^{* * * *} \\
(8.46)\end{array}$ & $\begin{array}{l}0.80^{* * * *} \\
(6.38)\end{array}$ \\
\hline IntCov & $\begin{array}{c}0.00091^{* * *} \\
(2.82)\end{array}$ & $\begin{array}{c}0.00070 \\
(1.57)\end{array}$ & $\begin{array}{c}0.00068 \\
(1.54)\end{array}$ & $\begin{array}{c}0.00094^{* * * *} \\
(2.86)\end{array}$ & $\begin{array}{c}0.00091^{* *} \\
(2.03)\end{array}$ \\
\hline Stake & $\begin{array}{r}-0.0057 \\
(-0.75)\end{array}$ & $\begin{array}{c}-0.0026 \\
(-0.31)\end{array}$ & $\begin{array}{c}-0.0043 \\
(-0.51)\end{array}$ & $\begin{array}{c}-0.0016^{* * * *} \\
(-3.90)\end{array}$ & $\begin{array}{c}-0.0051 \\
(-1.31)\end{array}$ \\
\hline ESG-perform & $\begin{array}{c}0.12^{* * *} \\
(3.68)\end{array}$ & & $\begin{array}{l}0.034 \\
(0.65)\end{array}$ & $\begin{array}{r}0.0077 \\
(0.17)\end{array}$ & \\
\hline ESG-disclose & & $\begin{array}{c}0.17^{* * * *} \\
(3.24)\end{array}$ & $\begin{array}{l}0.23^{* *} \\
(2.53)\end{array}$ & & $\begin{array}{c}0.89 \\
(0.96)\end{array}$ \\
\hline ESG-perform*ESG-disclose & & & $\begin{array}{c}0.29^{* * *} \\
(2.83)\end{array}$ & & \\
\hline ESG-perform*Stake & & & & $\begin{array}{l}0.18^{* * * *} \\
(3.90)\end{array}$ & \\
\hline ESG-disclose* Stake & & & & & $\begin{array}{c}0.12 \\
(1.44)\end{array}$ \\
\hline Constant & $\begin{array}{l}-1.38^{* * * *} \\
(-19.7)\end{array}$ & $\begin{array}{c}-1.26^{* * *} \\
(-13.6)\end{array}$ & $\begin{array}{c}-1.24^{* * *} \\
(-12.6)\end{array}$ & $\begin{array}{l}-1.35^{* * * *} \\
(-16.0)\end{array}$ & $\begin{array}{l}-1.25^{* * *} \\
(-10.4)\end{array}$ \\
\hline $\mathrm{N}$ & 1,330 & 1,000 & 1,000 & 1,330 & 1,000 \\
\hline $\operatorname{adj} . R^{2}$ & 0.436 & 0.361 & 0.365 & 0.404 & 0.310 \\
\hline Year dummies & Yes & Yes & Yes & Yes & Yes \\
\hline Industry dummies & Yes & Yes & Yes & Yes & Yes \\
\hline
\end{tabular}

The sample comprises of 1,330 firm-year observations over the period 2005 to 2016. Appendix A outlines definitions and data sources for all variables.

*** $\mathrm{p}$-value $<0.01, * * \mathrm{p}$-value $<0.05, * \mathrm{p}$-value $<0.1$. $t$-statistics in parentheses and italic 
Table 7: The endogeneity tests

\begin{tabular}{|c|c|c|c|c|}
\hline & $\begin{array}{l}\text { IV } \\
(1)\end{array}$ & $\begin{array}{l}\text { IV } \\
(2)\end{array}$ & $\begin{array}{c}\text { GMM } \\
\text { (3) }\end{array}$ & $\begin{array}{c}\text { GMM } \\
(4)\end{array}$ \\
\hline$L E V$ & $\begin{array}{l}0.11^{* * * *} \\
(17.8)\end{array}$ & $\begin{array}{c}0.091^{* * * *} \\
(13.0)\end{array}$ & $\begin{array}{l}0.72^{* * * *} \\
(8.46)\end{array}$ & $\begin{array}{l}0.89^{* * * *} \\
(7.41)\end{array}$ \\
\hline Size & $\begin{array}{c}0.00024 \\
(0.16)\end{array}$ & $\begin{array}{c}-0.0048^{* * * *} \\
(-2.82)\end{array}$ & $\begin{array}{c}-0.051^{* * * *} \\
(-5.51)\end{array}$ & $\begin{array}{c}-0.042^{* * * *} \\
(-3.00)\end{array}$ \\
\hline$R O A$ & $\begin{array}{l}-0.0041 \\
(-0.31)\end{array}$ & $\begin{array}{l}-0.011 \\
(-0.63)\end{array}$ & $\begin{array}{l}-0.67^{* * * *} \\
(-3.14)\end{array}$ & $\begin{array}{l}-0.40 \\
(-1.50)\end{array}$ \\
\hline IntCov & $\begin{array}{c}-0.000046^{* * *} \\
(-4.99)\end{array}$ & $\begin{array}{c}-0.000029^{* * *} \\
(-2.97)\end{array}$ & $\begin{array}{c}-0.00034^{* *} \\
(-2.10)\end{array}$ & $\begin{array}{c}-0.000072 \\
(-0.34)\end{array}$ \\
\hline Stake & $\begin{array}{c}-0.0050^{* * * *} \\
(-5.03)\end{array}$ & $\begin{array}{c}-0.0057^{* * *} \\
(-4.79)\end{array}$ & $\begin{array}{c}-0.046^{* * *} \\
(-3.95)\end{array}$ & $\begin{array}{c}-0.064^{* * *} \\
(-4.18)\end{array}$ \\
\hline ESG-perform & $\begin{array}{c}-0.077^{* * *} \\
(-5.39)\end{array}$ & & $\begin{array}{l}-0.10^{* * *} \\
(-1.98)\end{array}$ & \\
\hline $\begin{array}{l}\text { ESG-disclose } \\
\text { ESG-perform*ESG- } \\
\text { disclose }\end{array}$ & & $\begin{array}{l}-0.026^{*} \\
(-1.72)\end{array}$ & & $\begin{array}{l}-0.35^{* * * *} \\
(-2.97)\end{array}$ \\
\hline Lag cost of debt & & & $\begin{array}{l}3.74^{* * * *} \\
(26.2)\end{array}$ & $\begin{array}{l}4.02^{* * * *} \\
(17.3)\end{array}$ \\
\hline Constant & $\begin{array}{l}0.14^{* * * *} \\
(9.90) \\
\end{array}$ & $\begin{array}{c}0.17^{* * * *} \\
(8.78) \\
\end{array}$ & $\begin{array}{l}-2.01^{* * * *} \\
(-14.0) \\
\end{array}$ & $\begin{array}{c}-2.10^{* * * *} \\
(-9.42) \\
\end{array}$ \\
\hline $\begin{array}{l}\mathrm{N} \\
\text { adj. } \mathrm{R}^{2}\end{array}$ & $\begin{array}{l}6,007 \\
0.060\end{array}$ & $\begin{array}{l}3,384 \\
0.095\end{array}$ & 5,269 & 3,276 \\
\hline Year dummies & Yes & Yes & Yes & Yes \\
\hline Industry dummies & Yes & Yes & No & No \\
\hline
\end{tabular}

The sample ranges between 3,276 and 6,007 firm-year observations over the period 2005 to 2016. Models 1-2 use the instrumental estimation approach. Models 3-5 are estimated using the system GMM technique after adding lag of the cost of debt to the models as explanatory variable. Appendix A outlines definitions and data sources for all variables.

$* * * \mathrm{p}$-value $<0.01, * * \mathrm{p}$-value $<0.05, * \mathrm{p}$-value $<0.1 . t$-statistics in parentheses and italic 
Table 8: Pooled regressions of ESG performance and ESG disclosure on the cost of debt after excluding the UK

\begin{tabular}{|c|c|c|c|c|c|}
\hline & $(1)$ & $(2)$ & (3) & (4) & $(5)$ \\
\hline$\overline{L E V}$ & $\begin{array}{l}0.066^{* * *} \\
(12.3)\end{array}$ & $\begin{array}{c}0.073^{* * * *} \\
(10.7)\end{array}$ & $\begin{array}{c}0.073^{* * * *} \\
(10.7)\end{array}$ & $\begin{array}{c}0.066^{* * *} \\
(12.4)\end{array}$ & $\begin{array}{c}0.074^{* * *} \\
(10.8)\end{array}$ \\
\hline Size & $\begin{array}{c}-0.0024^{* * *} \\
(-3.28)\end{array}$ & $\begin{array}{c}-0.0016^{*} \\
(-1.69)\end{array}$ & $\begin{array}{c}-0.0021^{* *} \\
(-2.23)\end{array}$ & $\begin{array}{c}-0.0025^{* * *} \\
(-3.40)\end{array}$ & $\begin{array}{c}-0.0017^{*} \\
(-1.84)\end{array}$ \\
\hline$R O A$ & $\begin{array}{l}-0.0022 \\
(-0.18)\end{array}$ & $\begin{array}{l}0.0013 \\
(0.072)\end{array}$ & $\begin{array}{l}0.0012 \\
(0.068)\end{array}$ & $\begin{array}{l}-0.0014 \\
(-0.11)\end{array}$ & $\begin{array}{l}0.0052 \\
(0.29)\end{array}$ \\
\hline $\operatorname{IntCov}$ & $\begin{array}{c}-0.000018^{* *} \\
(-2.10)\end{array}$ & $\begin{array}{c}-0.0000040 \\
(-0.45)\end{array}$ & $\begin{array}{c}-0.0000026 \\
(-0.28)\end{array}$ & $\begin{array}{l}-0.000018^{* *} \\
(-2.13)\end{array}$ & $\begin{array}{c}-0.0000039 \\
(-0.43)\end{array}$ \\
\hline Stake & $\begin{array}{c}-0.0022^{* * *} \\
(-2.66)\end{array}$ & $\begin{array}{c}-0.0031^{* * * *} \\
(-3.02)\end{array}$ & $\begin{array}{c}-0.0030^{* * *} \\
(-2.89)\end{array}$ & $\begin{array}{l}0.0043^{* *} \\
(2.21)\end{array}$ & $\begin{array}{c}0.0046^{*} \\
(1.72)\end{array}$ \\
\hline ESG-perform & $\begin{array}{c}-0.021^{* * * *} \\
(-5.91)\end{array}$ & & $\begin{array}{c}-0.024^{* * *} \\
(-3.91)\end{array}$ & $\begin{array}{c}-0.000095^{* *} \\
(-2.05)\end{array}$ & \\
\hline ESG-disclose & & $\begin{array}{c}-0.036^{* * *} \\
(-4.95)\end{array}$ & $\begin{array}{l}-0.015 \\
(-1.42)\end{array}$ & & $\begin{array}{l}-0.012 \\
(-1.09)\end{array}$ \\
\hline ESG-perform*ESG-disclose & & & $\begin{array}{l}0.018^{*} \\
(1.92)\end{array}$ & & \\
\hline ESG-perform*Stake & & & & $\begin{array}{c}-0.010^{* * *} \\
(-3.70)\end{array}$ & \\
\hline ESG-disclose*Stake & & & & & $\begin{array}{c}-0.021^{* * *} \\
(-3.10)\end{array}$ \\
\hline Constant & $\begin{array}{l}0.13^{* * * *} \\
(12.2)\end{array}$ & $\begin{array}{l}0.11^{* * * *} \\
(7.97)\end{array}$ & $\begin{array}{l}0.13^{* * *} \\
(8.57) \\
\end{array}$ & $\begin{array}{l}0.12^{* * *} \\
(11.5)\end{array}$ & $\begin{array}{l}0.11^{* * * *} \\
(7.42)\end{array}$ \\
\hline $\begin{array}{l}\mathrm{N} \\
\text { adj. } \mathrm{R}^{2}\end{array}$ & $\begin{array}{l}3,650 \\
0.074\end{array}$ & $\begin{array}{l}2,198 \\
0.081\end{array}$ & $\begin{array}{l}2,198 \\
0.078\end{array}$ & $\begin{array}{l}3,650 \\
0.078 \\
\end{array}$ & $\begin{array}{l}2,198 \\
0.084\end{array}$ \\
\hline
\end{tabular}

The sample after excluding the UK ranges between 2,198 and 3,650 firm-year observations over the period 2005 to 2016. Appendix A outlines definitions and data sources for all variables.

$* * *$ p-value $<0.01$, ** p-value $<0.05, *$ p-value $<0.1 . t$-statistics in parentheses and italic 
Table 9: Fixed-effect panel regression of ESG performance and ESG disclosure on the cost of debt

\begin{tabular}{|c|c|c|c|c|c|}
\hline \multirow{3}{*}{$L E V$} & (1) & (2) & (3) & (4) & $(5)$ \\
\hline & $0.100^{* * * *}$ & $0.13^{* * *}$ & $0.13^{* * *}$ & $0.100^{* * * *}$ & $0.13^{* * *}$ \\
\hline & $(-10.8)$ & $(-9.59)$ & $(-9.65)$ & $(-10.8)$ & $(-9.60)$ \\
\hline \multirow[t]{2}{*}{ Size } & $-0.014^{* * *}$ & $-0.017^{* * *}$ & $-0.016^{* * *}$ & $-0.014^{* * *}$ & $-0.017^{* * *}$ \\
\hline & $(-5.79)$ & $(-4.57)$ & $(-4.15)$ & $(-5.78)$ & $(-4.57)$ \\
\hline \multirow[t]{2}{*}{$R O A$} & -0.0030 & -0.015 & -0.011 & 0.0030 & -0.015 \\
\hline & $(-0.23)$ & $(-0.77)$ & $(-0.57)$ & $(0.24)$ & $(-0.77)$ \\
\hline IntCov & $\begin{array}{c}-0.000030^{* * *} \\
(-3.18)\end{array}$ & $\begin{array}{c}-0.0000061 \\
(-0.52)\end{array}$ & $\begin{array}{c}-0.0000056 \\
(-0.48)\end{array}$ & $\begin{array}{c}0.000031^{* * * *} \\
(3.20)\end{array}$ & $\begin{array}{c}-0.0000062 \\
(-053)\end{array}$ \\
\hline \multirow[t]{2}{*}{ Stake } & 0.00047 & -0.0024 & -0.0024 & 0.0022 & -0.0034 \\
\hline & $(0.28)$ & $(-1.23)$ & $(-1.24)$ & $(0.63)$ & $(-0.75)$ \\
\hline ESG-perform & $\begin{array}{c}-0.018^{* * * *} \\
(-3.65)\end{array}$ & & $\begin{array}{l}-0.010 \\
(0.66)\end{array}$ & $\begin{array}{l}-0.016^{* *} \\
(-2.39)\end{array}$ & \\
\hline ESG-disclose & & $\begin{array}{l}-0.027^{* *} \\
(-2.23)\end{array}$ & $\begin{array}{c}-0.00053 \\
(1.11)\end{array}$ & & $\begin{array}{l}-0.030^{*} \\
(-1.74)\end{array}$ \\
\hline $\begin{array}{l}\text { ESG-perform*ESG- } \\
\text { disclose }\end{array}$ & & & $\begin{array}{c}0.00090^{*} \\
(1.68)\end{array}$ & & \\
\hline ESG-perform* ${ }^{*}$ Stake & & & & $\begin{array}{l}-0.0024 \\
(-0.56)\end{array}$ & \\
\hline ESG-disclose*Stake & & & & & $\begin{array}{l}-0.0025 \\
(-0.25)\end{array}$ \\
\hline Constant & $\begin{array}{l}0.31^{* * *} \\
(8.83)\end{array}$ & $\begin{array}{l}0.37^{* * *} \\
(6.54) \\
\end{array}$ & $\begin{array}{l}0.34^{* * *} \\
(5.86)\end{array}$ & $\begin{array}{l}0.31^{* * *} \\
(8.72)\end{array}$ & $\begin{array}{l}0.37^{* * *} \\
(6.54) \\
\end{array}$ \\
\hline $\begin{array}{l}\mathrm{N} \\
\operatorname{adj} . \mathrm{R}^{2}\end{array}$ & $\begin{array}{c}6,018 \\
0.0907\end{array}$ & $\begin{array}{c}3,384 \\
0.0822\end{array}$ & $\begin{array}{c}3,384 \\
0.0831\end{array}$ & $\begin{array}{c}6,018 \\
0.0910\end{array}$ & $\begin{array}{c}3,384 \\
0.0820\end{array}$ \\
\hline
\end{tabular}

The sample comprises of 6,018 firm-year observations over the period 2005 to 2016. Appendix A outlines definitions and data sources for all variables.

$* * * \mathrm{p}$-value $<0.01, * * \mathrm{p}$-value $<0.05, * \mathrm{p}$-value $<0.1 . t$-statistics in parentheses and italic 
Appendix A. Variable definitions and data sources

\begin{tabular}{|c|c|c|}
\hline Variable & Definition & Source \\
\hline \multicolumn{3}{|c|}{ Panel A. Dependent variables } \\
\hline$C o D$ & $\begin{array}{l}\text { The cost of debt calculated as the ratio of a firm's } \\
\text { interest expense to the average debt. }\end{array}$ & $\begin{array}{l}\text { The Thomson Reuters } \\
\text { DataStream database }\end{array}$ \\
\hline Credit Ratings & 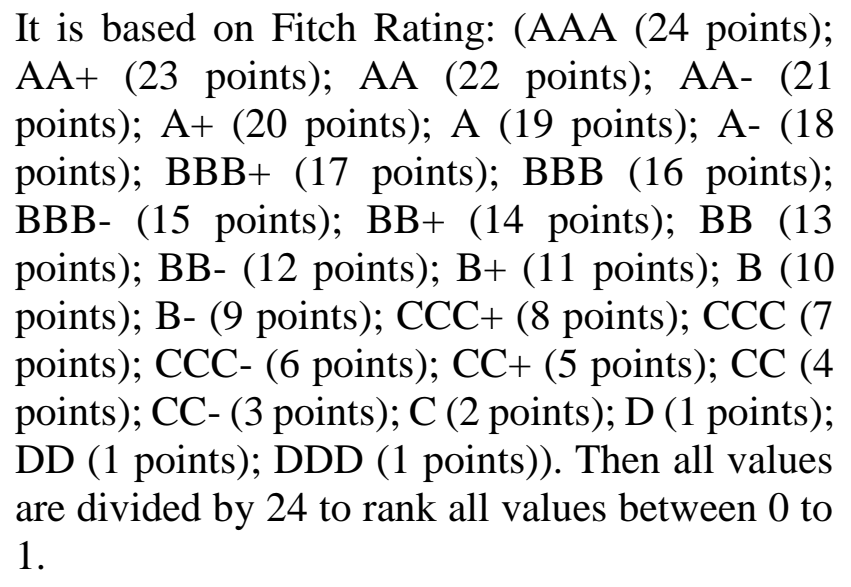 & $\begin{array}{l}\text { The Thomson Reuters } \\
\text { Asset } 4 \text { database }\end{array}$ \\
\hline \multicolumn{3}{|c|}{ Panel B. ESG variables } \\
\hline ESG-perform & $\begin{array}{l}\text { ESG performance based on Thomson Reuters } \\
\text { ESG ratings, which are designed to measure a } \\
\text { firm's relative ESG performance, commitment } \\
\text { and effectiveness across three main dimensions; } \\
\text { the environmental dimension, the social } \\
\text { dimension and governance dimension. }\end{array}$ & $\begin{array}{l}\text { The Thomson Reuters } \\
\text { Asset } 4 \text { database }\end{array}$ \\
\hline ESG-disclosure & $\begin{array}{l}\text { ESG disclosure based on the Bloomberg database } \\
\text { index, which are designed to measure a firm's } \\
\text { relative ESG disclosure based on the information } \\
\text { available in firms' annual reports, corporate } \\
\text { social responsibility reports, and firms' websites. }\end{array}$ & $\begin{array}{l}\text { The Bloomberg } \\
\text { Database }\end{array}$ \\
\hline $\begin{array}{l}\text { Environmental- } \\
\text { perform }\end{array}$ & $\begin{array}{l}\text { The environmental dimension of ESG } \\
\text { performance. }\end{array}$ & $\begin{array}{l}\text { The Thomson Reuters } \\
\text { Asset4 database }\end{array}$ \\
\hline Social-perform & The social dimension of ESG performance. & $\begin{array}{l}\text { The Thomson Reuters } \\
\text { Asset } 4 \text { database }\end{array}$ \\
\hline $\begin{array}{l}\text { Governance- } \\
\text { perform }\end{array}$ & The governance dimension of ESG performance. & $\begin{array}{l}\text { The Thomson Reuters } \\
\text { Asset } 4 \text { database }\end{array}$ \\
\hline $\begin{array}{l}\text { Environmental- } \\
\text { disclose }\end{array}$ & $\begin{array}{l}\text { The environmental dimension of ESG } \\
\text { disclosure. }\end{array}$ & $\begin{array}{l}\text { The Bloomberg } \\
\text { Database }\end{array}$ \\
\hline
\end{tabular}




\begin{tabular}{|c|c|c|}
\hline Social- disclose & The social dimension of ESG disclosure. & $\begin{array}{l}\text { The Bloomberg } \\
\text { Database }\end{array}$ \\
\hline $\begin{array}{l}\text { Governance- } \\
\text { disclose }\end{array}$ & The governance dimension of ESG disclosure. & $\begin{array}{l}\text { The Bloomberg } \\
\text { Database }\end{array}$ \\
\hline \multicolumn{3}{|c|}{ Panel C. Control variables } \\
\hline Size & $\begin{array}{l}\text { Firm size calculated as a natural logarithm of total } \\
\text { assets. }\end{array}$ & $\begin{array}{l}\text { The Thomson Reuters } \\
\text { DataStream database }\end{array}$ \\
\hline$L E V$ & $\begin{array}{l}\text { Leverage ratio calculated as total debt of a firm } \\
\text { deflated by total assets. }\end{array}$ & $\begin{array}{l}\text { The Thomson Reuters } \\
\text { DataStream database }\end{array}$ \\
\hline$R O A$ & $\begin{array}{l}\text { Return on assets calculated as net income before } \\
\text { extraordinary items deflated by total assets. }\end{array}$ & $\begin{array}{l}\text { The Thomson Reuters } \\
\text { DataStream database }\end{array}$ \\
\hline $\operatorname{IntCov}$ & $\begin{array}{l}\text { Interest coverage is calculated as total operating } \\
\text { income deflated by total interest expense. }\end{array}$ & $\begin{array}{l}\text { The Thomson Reuters } \\
\text { DataStream database }\end{array}$ \\
\hline Stake & $\begin{array}{l}\text { Country's stakeholder orientation calculated as } \\
\text { the average of a country level score of } \\
\text { stakeholders orientation developed by Dhaliwal } \\
\text { et al. (2012) with a higher value indicating greater } \\
\text { stakeholders orientation. }\end{array}$ & Dhaliwal et al. (2012) \\
\hline
\end{tabular}

